UNIVERSIDADE DE BRASÍLIA - UNB

FACULDADE DE ECONOMIA, ADMINISTRAÇÃO, CONTABILIDADE E CIÊNCIA DA INFORMAÇÃO E DOCUMENTAÇÃO - FACE

EDILENE DOS REIS ROCHA ARAÚJO

\title{
DÍVIDA LÍQUIDA DO SETOR PÚBLICO: UMA ANÁLISE DA EVOLUÇÃO RECENTE DO ENDIVIDAMENTO PÚBLICO
}

Brasília - DF 


\title{
DÍVIDA LÍQUIDA DO SETOR PÚBLICO: UMA ANÁLISE DA EVOLUÇÃO RECENTE DO ENDIVIDAMENTO PÚBLICO
}

\author{
Monografia apresentada ao Programa \\ de Pós-Graduação em Administração \\ (PPGA) da Faculdade de Economia, \\ Administração, Contabilidade e Ciência \\ da Informação e Documentação \\ (FACE), da Universidade de Brasília, \\ como requisito parcial à obtenção do \\ grau de Especialista em Orçamento e \\ Finanças.
}

Orientador: Prof. Me. Otavio Ladeira Medeiros

Brasília - DF 
Dedico este trabalho a Maria Reis, minha mãe, a Mário Lucio, meu esposo, e aos meus filhos, Ana Paula e Artur, que são parte de mim e de tudo que consegui conquistar. 


\section{AGRADECIMENTOS}

Agradeço em especial a Deus, que me acompanha a todo instante, à minha mãe, que me apoiou durante a realização do curso e desenvolvimento deste trabalho, ao meu esposo pela paciência, sabedoria e carinho dedicados nos momentos difíceis, aos colegas de curso pelas novas amizades, experiências e conhecimentos compartilhados, ao meu orientador, o professor Otavio Ladeira Medeiros, aos demais professores e funcionários da UNB e ao SERPRO pelo aprendizado proporcionado. 


\section{RESUMO}

O presente trabalho dedicou-se ao estudo da Dívida Líquida do Setor Público - DLSP, e de seus principais condicionantes (PIB, Câmbio, Juros Reais e Resultado Primário), com o objetivo de buscar evidências empíricas que pudessem explicar a sua evolução no período de 1995 a 2008. A análise possibilitou comparar os resultados obtidos, observando as formas de gestão adotadas no período. Os resultados apontaram que a Dívida Líquida do Setor Público possui relação de longo prazo com as demais variáveis estudadas. No período 1995-2008, a variação da dívida decorreu principalmente da sua própria variação e, em seguida, da variação dos juros reais. Entretanto, observando somente o período 1999-2008, o resultado primário ocupa o lugar dos juros, sendo o segundo responsável pela variação da dívida. Essa evolução se explica pelos resultados obtidos com a adoção de novas estratégias por parte do governo a partir de 1999.

PALAVRAS-CHAVES: Dívida, Setor Público, Endividamento. 


\section{LISTA DE FIGURAS}

Figura 1. Pagamento de juros e Resultado primário - amostra de países dados 2001 (\% PIB)

Figura 2. Função Impulso Resposta para IDLSP

\section{LISTA DE QUADROS}

Quadro 1. Principais indexadores da Dívida Pública Brasileira

Quadro 2. Perfil do Endividamento da Dívida Pública Brasileira

Quadro 3. Fatores condicionantes da Evolução da Dívida Líquida (1996-2001)

Quadro 4. Fatores condicionantes da Evolução da Dívida Líquida (2002-2008)

Quadro 5. Resultados para os testes de estacionariedade -ADF 42

Quadro 6. Resultados para o teste de cointegração sem traço 43

Quadro 7. Critério de seleção de Defasagem do VAR 43

Quadro 8. Resultados para Decomposição da Variância (período jan/96 a dez/08) 45

Quadro 9. Resultados para Decomposição da Variância (período jan/99 a dez/08) 


\section{LISTA DE GRÁFICOS}

Gráfico 1. Evolução da Dívida Líquida do Setor Público (1995-2007) - R\$ Milhões 18

Gráfico 2. Evolução da DLSP Interna e Externa (1995-2007) - \% PIB 19

Gráfico 3. Evolução da Dívida Líquida do Setor Público (\% do PIB) 19

Gráfico 4. Dívida Líquida do Setor Público - Participação percentual por 22 indexador

Gráfico 5. Resultado Primário do Setor Público Consolidado 30

Gráfico 6. Composição da Dívida Líquida do Setor Público 34

Gráfico 7. Evolução da Dívida Líquida Setor Público e PIB - R \$ milhões 35

Gráfico 8. Dívida Líquida do Setor Público, 2002-2011 -Exercícios com taxas de 36 crescimento (\%PIB)

Gráfico 9. Taxa de variação real do PIB (\%) - 2004 a 2008 


\section{SUMÁRIO}

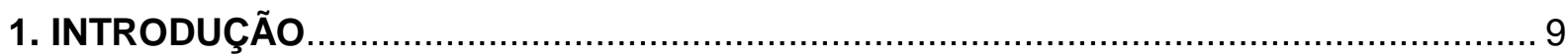

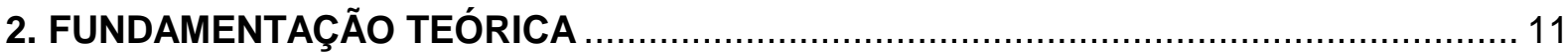

2.1. Dívida Líquida do Setor Público (DLSP) e Dívida Bruta do Governo Geral (DBGG). 11

2.1.1. Financiamento dos Gastos Públicos e o Endividamento .......................... 12

2.1.2. Evolução da Dívida Pública....................................................................... 15

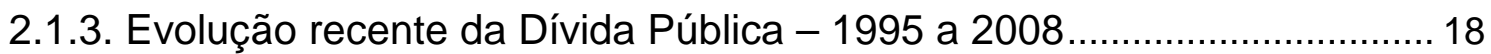

2.1.4. Evolução da Composição, Custo e Prazo da DLSP .................................. 20

2.1.5. Sustentabilidade da Dívida Pública .......................................................... 24

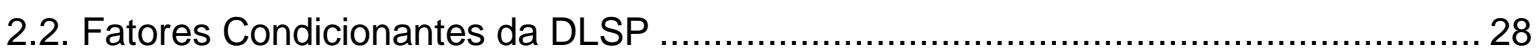

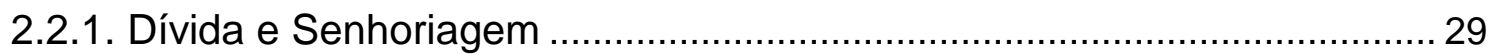

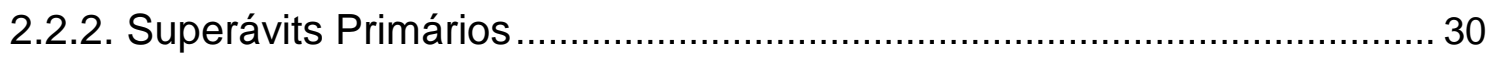

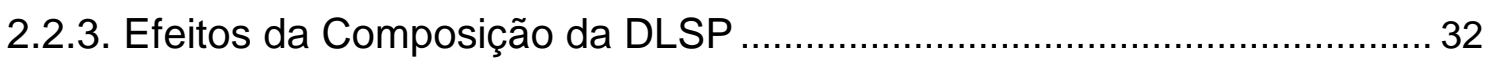

2.2.4. Dívida Líquida do Setor Público e o Crescimento Econômico (PIB) ........ 35

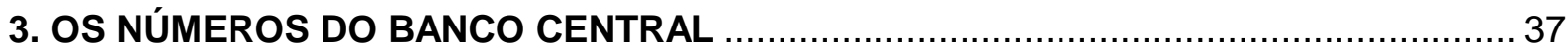

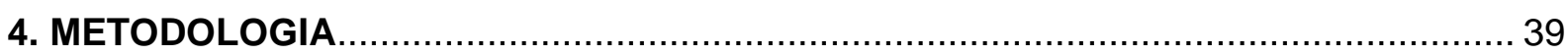

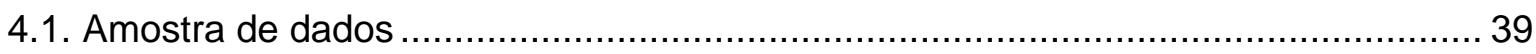

4.2. Instrumentos e Procedimentos ............................................................................ 40

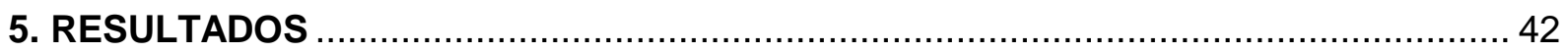

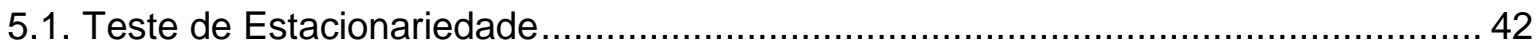

5.2. Teste de co-integração de Johansen .............................................................. 42

5.3. Modelo VAR para Dívida Líquida do Setor Público - 1995 à 2008 .......................... 43

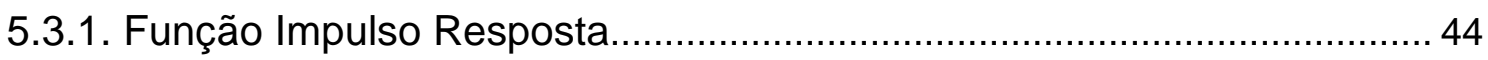

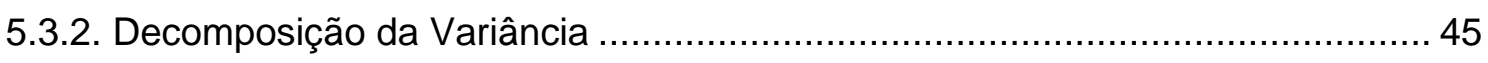

5.3.3. Modelo VAR para Dívida Líquida do Setor Público - 1999 à $2008 \ldots \ldots \ldots \ldots \ldots \ldots . . . . . . . . .47$

6. DISCUSSÃO DOS RESULTADOS E CONCLUSÕES …........................................ 49

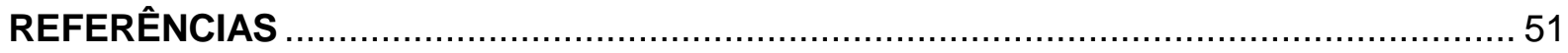




\section{INTRODUÇÃO}

Nos últimos anos, percebeu-se um aumento do número de debates acerca da atuação do governo na economia. No Brasil, esse aumento deveu-se, em grande parte, aos sucessivos déficits fiscais e à evolução do endividamento público.

Segundo argumentação de Mendonça (2005) a dívida pública é uma condicionante essencial da capacidade de gasto e da necessidade de geração de receitas e, como ela traz implicações para todas as variáveis econômicas relevantes da economia, tem sido recorrente no debate sobre política econômica não somente no Brasil como também no mundo.

A dívida pública brasileira cresceu cerca de 40 mil por cento no período de 1964/1979 e, com a crise da dívida em 1982, cresceu mais cerca de $480 \%$.

Na década de 1990 o Brasil enfrentou problemas relacionados a preços e credibilidade, situação influenciada pelo problema de inflação crônica em que o país se encontrava.

Em 1994, de acordo com Rezende (2001), a Dívida Líquida do Setor Público (DLSP) era de $28,5 \%$ em relação ao Produto Interno Bruto (PIB). Essa relação evoluiu para $42,6 \%$ em 1998, chegando a $50 \%$ em 1999. Com essa evolução surgiu a necessidade de maior controle da relação DLSP/PIB a fim de se reverter essa trajetória de ascensão.

A questão fiscal, desde então, teve destaque nas discussões econômicas. Reformas foram implementadas com o objetivo de se obter maior controle dos gastos públicos, primando-se pela geração de superávits primários.

Com a geração de superávits primários, de acordo com Rezende (2001), o governo estaria reduzindo suas necessidades de financiamento, possibilitando a queda da taxa de juros e estimulando os investimentos privados e o crescimento econômico.

Dado o panorama acima, a riqueza de informações que se pode prover, e por considerar a dívida pública um tema relevante, o presente trabalho dedicou-se ao estudo da evolução da DLSP e de seus condicionantes, buscando evidências empíricas que possam explicar a sua evolução no período de 1995 a 2008. 
O período a ser estudado envolve duas formas de gestão: de 1995 a 1998 o governo utilizou a política fiscal não restritiva; a partir de 1999 o governo mudou de estratégia e adotou a política fiscal severa de obtenção de superávits primários. Com isso, a análise possibilitará comparar os resultados obtidos com a forma de gestão adotada.

Camuri (2005), em uma análise acerca do endividamento público brasileiro, estudou a relação entre as variáveis condicionantes da dívida, tais como taxa de juros, resultado primário, taxa de câmbio, inflação, reservas internacionais, dentre outras, com a Dívida Pública Brasileira, para o período de 1994-2004. Os resultados empíricos apontaram a participação de cada variável na evolução do endividamento no período.

Este trabalho tem como base o estudo realizado pelo autor, utilizando-se um intervalo de tempo diferenciado, período de janeiro de 1995 a dezembro de 2008, e expurgando-se os efeitos das crises externas. Além disso, será utilizada a DLSP em valor corrente e não a proporção da Dívida em relação ao PIB (DLSP/PIB) para que seja possível avaliar a participação do crescimento econômico na evolução da dívida pública e analisar o impacto das demais variáveis com este novo intervalo.

Para melhor entendimento dessas relações econômicas oriundas de déficits públicos e do processo de endividamento é realizada, no capítulo 2, a revisão de conceito sobre DLSP, sua origem e evolução. É apresentada também a evolução da composição da dívida pública no período, indicando as diretrizes estabelecidas pelo governo e o papel dessas diretrizes no gerenciamento da dívida. Ainda nesse capítulo são abordados os fatores condicionantes da dívida.

No capítulo 3 são discutidos os números divulgados pelo Banco Central do Brasil como fatores condicionantes da evolução da Dívida Pública Líquida. O capítulo 4 trata da metodologia empregada no desenvolvimento do trabalho.

No capítulo 5 são apresentados os resultados da análise empírica, com a utilização de procedimentos econométricos para avaliar a evolução das variáveis consideradas como influenciadoras do comportamento da dívida no curto e longo prazos. capítulo 6.

As discussões dos resultados e suas conclusões são apresentadas no 


\section{FUNDAMENTAÇÃO TEÓRICA}

Neste capítulo será apresentado o conceito de Dívida Líquida do Setor Público (DLSP) utilizado pelo governo, como é mensurada e quais os setores que compõem a mensuração. Será apresentada uma breve evolução histórica da Dívida, dando-se ênfase ao período de 1995 a 2008, sendo este dividido em dois subperíodos, para permitir a visualização dos resultados auferidos com as políticas econômicas utilizadas. Será apresentado também como se dá o financiamento dos gastos do governo e de que forma o financiamento desses gastos contribuiu para a evolução do endividamento. Será apresentado como o assunto tem sido abordado e de que forma o governo tem trabalhado para o alcance da estabilidade da dívida. Por fim, serão discutidos os fatores condicionantes da DLSP, incluindo-se os números apresentados pelo Banco Central para o período avaliado.

\subsection{Dívida Líquida do Setor Público (DLSP) e Dívida Bruta do Governo Geral (DBGG)}

Para melhor compreensão da dívida pública é necessário entender a diferença entre Dívida Líquida do Setor Público (DLSP) e Dívida Bruta do Governo Geral (DBGG). A DLSP, conforme definição do Banco Central, representa o balanceamento dos débitos e créditos do setor público, enquanto a DBGG traduz apenas os débitos do governo geral.

Há, portanto, duas diferenças básicas entre DLSP e DBGG. A primeira refere-se à abrangência. Nesse caso, a DLSP inclui todo o setor público não financeiro, englobando governo federal, Banco Central, governos estaduais, governos municipais e empresas estatais dos três níveis de governo. Já o indicador DBGG tem como abrangência apenas o segmento de Governo Geral, ou seja, governo federal, estados e municípios. A segunda refere-se à inclusão de recursos financeiros na apuração da DLSP.

O conceito de governo geral diferencia-se, portanto, do conceito de setor 
público, de uso mais tradicional no Brasil, por excluir o Banco Central e as empresas estatais, e foi introduzido para facilitar comparações internacionais, bem como para dimensionar o total dos débitos brutos de origem eminentemente fiscal, sem computar o efeito resultante de atividades empresariais do setor público, tampouco aquelas diretamente relacionadas com as funções do Banco Central.

Para a realização do trabalho será considerada a DLSP em razão de esse indicador ser o mais utilizado para o acompanhamento da dívida e a verificação de sua sustentabilidade.

Para efeito didático, Muntada (2006) propõe a apuração da dívida pública conforme a equação descrita a seguir:

$$
D L S P=M+B+I-A+F-R
$$

Onde: $\quad M=$ Base Monetária;

B = Dívida Interna Indexada a índices internos;

I = Dívida Interna indexada ao câmbio;

$A=$ Ativos financeiros do setor público;

$\mathrm{F}=$ Dívida externa; e

$R=$ Reservas internacionais.

Assim, a variação da dívida pública dá-se em função da variação desses componentes, que são influenciados pela variação da taxa de câmbio, juros e demais índices internos que tenham sido objetos de indexação da dívida.

\subsubsection{Financiamento dos Gastos Públicos e o Endividamento}

Tradicionalmente o que se espera é que o governo trabalhe considerando a restrição orçamentária. Desta forma, os seus gastos deveriam ser limitados ao valor de sua arrecadação. Mas, normalmente, não é isso que ocorre.

Silva (2006), ao avaliar o equilíbrio intertemporal entre a arrecadação e os gastos do governo no período de 1995 a 2005, apresentou a evidência dinâmica de 
curto prazo de que para cada real gasto arrecada-se 93 centavos. O autor citou outros dois estudos: o primeiro, realizado para o período de 1989 a 1997, em que se apurou 94 centavos arrecadados para cada real gasto; e o segundo, de 1995 a 2002, em que foi apurado 83 centavos arrecadados para cada real gasto.

Considerando essa estatística, em que o governo gasta mais do que arrecada, cabe então esclarecer quais são os mecanismos utilizados pelo governo para obter os recursos necessários à cobertura dos gastos públicos.

De acordo com Albuquerque, Medeiros e Feijó (2008), há dois mecanismos: o primeiro compreende as fontes primárias, ou seja, as receitas de tributação, que pode também ser complementada pela exploração de ativos públicos, sem a contração de obrigação futura (dívida); o segundo, refere-se às fontes de financiamentos, em que o governo obtém recursos mediante contratação de dívida.

Assim, quando as receitas primárias do governo são insuficientes para as suas despesas ocorre o déficit primário. Com isso o governo é obrigado a utilizar outras fontes de financiamentos para cobrir esse déficit, gerando obrigações futuras e favorecendo o endividamento, ou seja, ampliando a dívida pública.

A Necessidade de Financiamento do Setor Público (NFSP), de acordo com Rezende (2001), é mensurada conforme equação a seguir:

$$
\left(G_{n f}-R_{n f}\right)+i_{t} D+i_{t}^{*} e_{t} F_{t}+i_{c} L_{t}=\Delta D_{t}+\Delta F+\Delta L
$$

A interpretação do autor para a equação é que o lado esquerdo apresenta as fontes de geração de déficit público. Em que $\left(G_{n f}-R_{n f}\right)$ representa a diferença entre os gastos não financeiros e as receitas não financeiras e os demais itens referem-se aos dispêndios financeiros líquidos ou pagamento de juros líquidos que incidem sobre os diversos estoques da dívida pública: a dívida interna contraída em moeda nacional $D_{t}$, a dívida contratada em moeda externa $F_{t}$, a dívida obtida junto ao Banco Central $L_{t}$ e as suas respectivas taxas $\left(i_{t}, i_{t}^{\star}, i_{c}\right)$. A variável $e$ representa a taxa de câmbio.

Já no lado direito tem-se as fontes de financiamentos dos gastos: a emissão de títulos domésticos $\Delta D_{t}$, a emissão de títulos externos $\Delta F_{t}$ e a emissão de títulos junto ao Banco Central $\Delta L_{t}$. 
Contudo, de acordo com Rezende (2001), as operações de empréstimos do Banco Central para o Tesouro Nacional, que correspondem a aumentos da base monetária, podem ocorrer também de forma indireta, por meio das compras em mercado aberto de títulos da dívida pública em poder do setor privado. Assim, para captar adequadamente as NFSP é necessário agregar às operações fiscais do setor público as mudanças ocorridas no âmbito do balanço do Banco Central, representadas na equação seguinte:

$$
M_{t}=L_{t}+e_{t} R_{t}-\pi
$$

Onde: $\quad$ é estoque de base monetária

L títulos públicos

$R$ reservas internacionais

$\pi$ representa os lucros ou prejuízos resultantes das operações do Banco Central.

Com o desenvolvimento das equações (2.1) e (2.2) tem-se a restrição orçamentária do setor público não financeiro mais o Banco Central.

$$
\left(G_{n f}-R_{n f}\right)+i_{t} D_{t}+i^{*}{ }_{t} e_{t}\left(F_{t}-R_{t}\right)+\Delta e_{t} R_{t}=\Delta M_{t}+\Delta D_{t}+e\left(\Delta F_{t}+\Delta R_{t}\right)
$$

Essa equação mostra como são calculadas as NFSP, trazendo, no lado direito, a representação da variação do estoque da dívida líquida do setor público (DLSP) entre dois períodos de tempo.

Assim, a equação (2.4) representa o cálculo das NFSP apuradas pelo Banco Central sob a ótica do financiamento:

$$
N F S P=\Delta D L S P=\Delta M_{t}+\Delta D_{t}+e\left(\Delta F_{t}+\Delta R_{t}\right)
$$

Em função das privatizações ocorridas a partir de 90 e o reconhecimento de dívidas passadas, que afetam a DLSP e a NFSP, o Banco Central passou a expurgar esses efeitos do ajuste patrimonial no cálculo nas NFSP, criando a Dívida Fiscal Líquida (DFL): 


$$
D F L=D L S P-A P_{t}=D L S P-(\text { Dívidas Passadas }- \text { Privatizações })
$$

Um nível elevado ou crescente de dívida poderá provocar, de acordo com Albuquerque, Medeiros e Feijó (2008), dificuldades macroeconômicas e criar desequilíbrios, aumentar a vulnerabilidade da posição fiscal e da taxa de câmbio a acontecimentos externos e perda de confiança na capacidade do governo em administrar suas finanças, justificando-se a questão da credibilidade e da importância da gestão da dívida e do resultado fiscal como indicadores de desempenho de uma economia.

De acordo com Bresser-Pereira (2004), com exceção do período entre 1990 e 1992, o que se fez desde a crise do Estado na década de 1980 foi aumentar a despesa pública, e aumentar correspondentemente a carga tributária, que cresceu de 22 para $35 \%$ do PIB. O autor argumenta que o objetivo da política fiscal não pode ser apenas o de aumentar o superávit primário, ou seja, o déficit público deduzido os juros, mas também eliminar o déficit público e alcançar poupança pública positiva, com a qual se possam financiar os investimentos públicos.

\subsubsection{Evolução da Dívida Pública}

De acordo com estudos da Associação Nacional das Instituições de Mercado Financeiro - ANDIMA, as origens da dívida pública remontam aos tempos da colônia, com empréstimos contraídos por alguns governadores desde os séculos XVI e XVII.

Hermann (2002) também argumenta que a dívida é uma instituição bastante antiga.

A dívida pública é uma instituição da vida econômica tão antiga quanto o próprio estado, integrando o conjunto de instrumentos gradativamente criados para financiar suas atividades. A emissão de moedas ou cunhagem de metais nos sistemas de moeda-mercadoria é, historicamente, a primeira forma de dívida pública conhecida (HERMANN, 2002, p.44). 
Herman (2002) relata que o endividamento formal do Estado junto aos bancos privados foi gradativamente se tornando uma prática comum, constituindo até 1940 uma fonte excepcional de financiamento do Estado.

Embora estudos já tratassem do assunto na década de trinta, de acordo com o autor, somente após a segunda guerra é que se percebe a sua influência decisiva na atuação do Estado na economia.

Assim, no que tange às experiências concretas de política fiscal e gestão da dívida pública, o autor identifica, grosso modo, três períodos distintos:

a) Do pós-guerra até fins de 1970: período de dominância Keynesiana, cujo objetivo central da gestão da dívida pública era obter uma boa administração da dívida, de forma manter baixo o custo de financiamento do governo;

b) Década de 80: caracterizada pelo esforço fiscal de caráter conjuntural, visando reduzir o déficit orçamentário no curto prazo, com cortes no gasto público ou aumento de impostos;

c) Década de 90 em diante: predominância do enfoque neoclássico, busca de orçamento fiscal equilibrado, visando a eliminação do déficit público e busca pela estabilização e redução da relação dívida/PIB.

Houve, de acordo com estudos da ANDIMA, um aumento de títulos públicos federais em circulação com a segunda guerra, porém nem todos foram resgatados. Com isso, na década de 1950 e de 1960 o mercado de títulos no Brasil perdia cada vez mais a credibilidade.

Diante da necessidade de recuperar o crédito, o governo realizou profundas reformas estruturais. Em 1964 foi criada a correção monetária e incentivou-se a intermediação financeira, que contribuiu para a recuperação da credibilidade dos títulos do governo, o que possibilitou o financiamento do déficit via emissão de títulos.

Isso explica, conforme estudo da ANDIMA, o aumento da dívida em cerca de 40 mil por cento no período de 1964/1979.

Com a crise da dívida em 1982, o governo priorizou o financiamento interno do déficit como única opção de fazer face aos gastos públicos. Com isso, na década de 1980 a dívida interna cresceu, em termos reais, cerca de $480 \%$.

Na década seguinte, 1990, o Brasil enfrentou problemas relacionados a 
preços e credibilidade, situação influenciada pelo problema de inflação crônica em que o país se encontrava.

De acordo com Benecke (2002), nos anos 90 a dívida pública cresceu quase na mesma dimensão que $\circ \mathrm{PIB}$, o que permite concluir que o crescimento econômico nessa época foi financiado principalmente com fundos externos e não com poupança da população.

Com isso Benecke visualiza dois problemas na questão do endividamento. O primeiro refere-se ao uso e o segundo à dimensão.

Quanto ao uso, existe, segundo o autor, uma regra clara de que utilizando o crédito gerado com endividamento para fins de uma produção rentável se abrem novas perspectivas, podendo gerar ou manter empregos, introduzir inovações, levando o país a condições melhores, permitindo o pagamento da dívida. Por outro lado, os créditos utilizados para o consumo normalmente criam novos ingressos. Isso alivia momentaneamente, mas agrava o problema no futuro.

Para o problema referente à dimensão foram citados pelo autor alguns critérios já estabelecidos na União Européia, no "Pacto de Estabilidade" do contrato de Maastricht de 1992, que limita o déficit fiscal a $3 \%$ e a dívida pública a $60 \%$ do PIB.

Giambiagi e Além (2001) argumentam que, de um modo geral, a dívida pode crescer indefinidamente, desde que a economia não deixe de crescer. O que não pode crescer sempre é a relação dívida PIB, pois em algum momento o credor pode perceber que a dívida é impagável, negar-se a conceder novos créditos ao governo e provocar a falência deste - e de si próprio, por ter no ativo papéis que podem não valer nada, da noite para o dia. Mas tão importante ou mais que o tamanho relativo da dívida é a sua estrutura, em que se considera o prazo de vencimento e a taxa de juros média que o governo paga.

Nesse sentido Benecke (2002) esclarece o que pode ocorrer no governo com um alto índice de endividamento:

Um endividamento alto e a disposição de reduzi-lo restringem ao governo a possibilidade de inversões em projetos produtivos, educação, investigação científica e outras atividades relevantes para o futuro do país (BENECKE, 2002, p.204). 


\subsubsection{Evolução recente da Dívida Pública - 1995 a 2008}

De janeiro de 1995 à dezembro de 2008 a dívida líquida do setor público evoluiu de $R \$ 208$ bilhões para $R \$ 1,069$ bilhões. A relação da dívida/PIB, que no final de 1995 era cerca de $28 \%$, saltou para 52\% em 2003, fechando 2008 em cerca de $36 \%$. A análise do Gráfico 1 a seguir nos dá a percepção da evolução e da dimensão da dívida no período.

Gráfico 1 - Evolução da Dívida Líquida do Setor Público

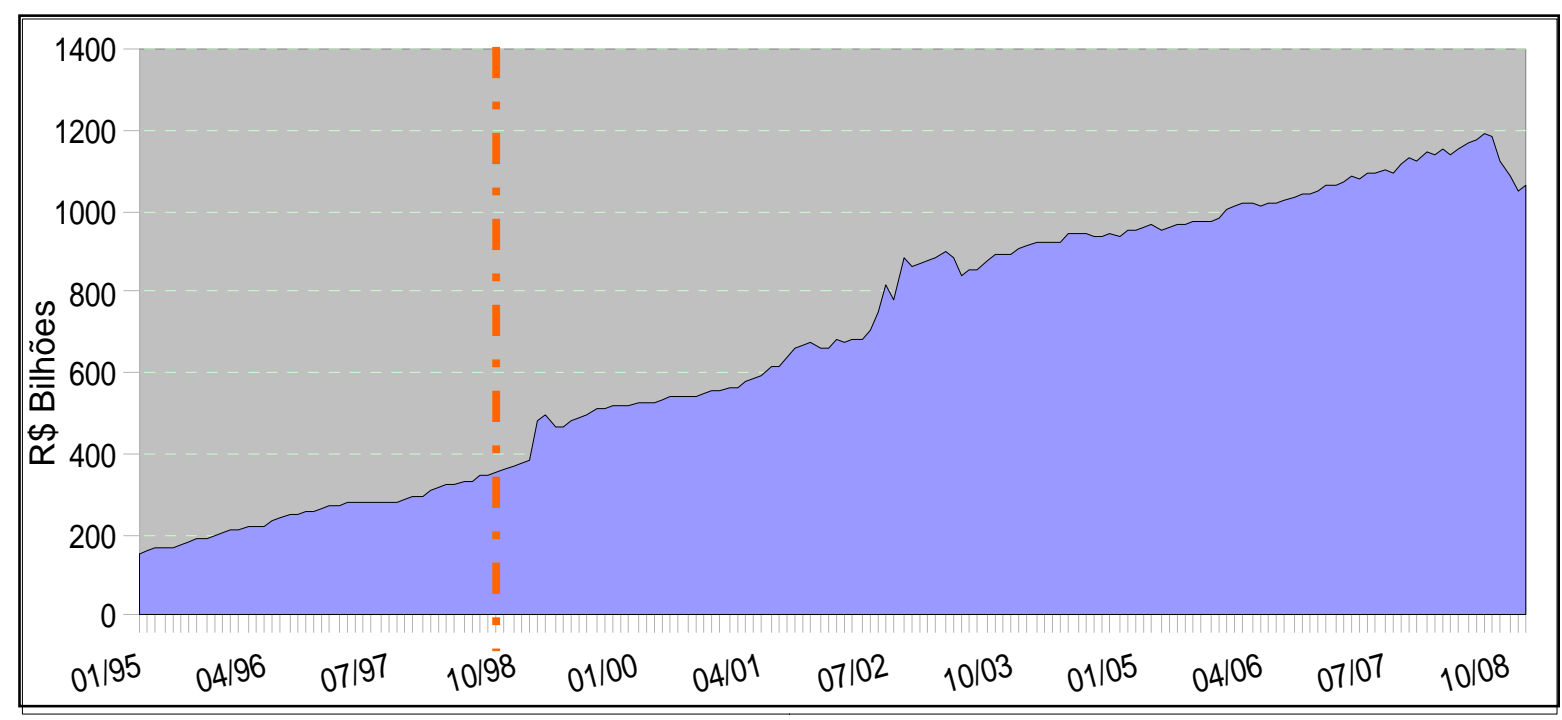

Fonte: Elaborado a partir de séries mensais, de jan/95 a dez/2008, do Banco Central

Dentre os principais fatores que motivaram essa evolução destacam-se as incorporações de dívidas não contabilizadas anteriormente, chamadas de "esqueletos", a ocorrência de suscetíveis déficits e o aumento da taxa de juros.

Além desses eventos, com a análise do Gráfico 2 apresentado a seguir, é possível identificar impactos que influenciaram fortemente a trajetória da dívida pública. Em 1995, houve a crise do México, em 1998 a crise da Rússia, em 1999 percebe-se uma quebra estrutural devido à flexibilização da taxa de câmbio no Brasil. 
Gráfico 2 - Evolução da DLSP Interna e Externa

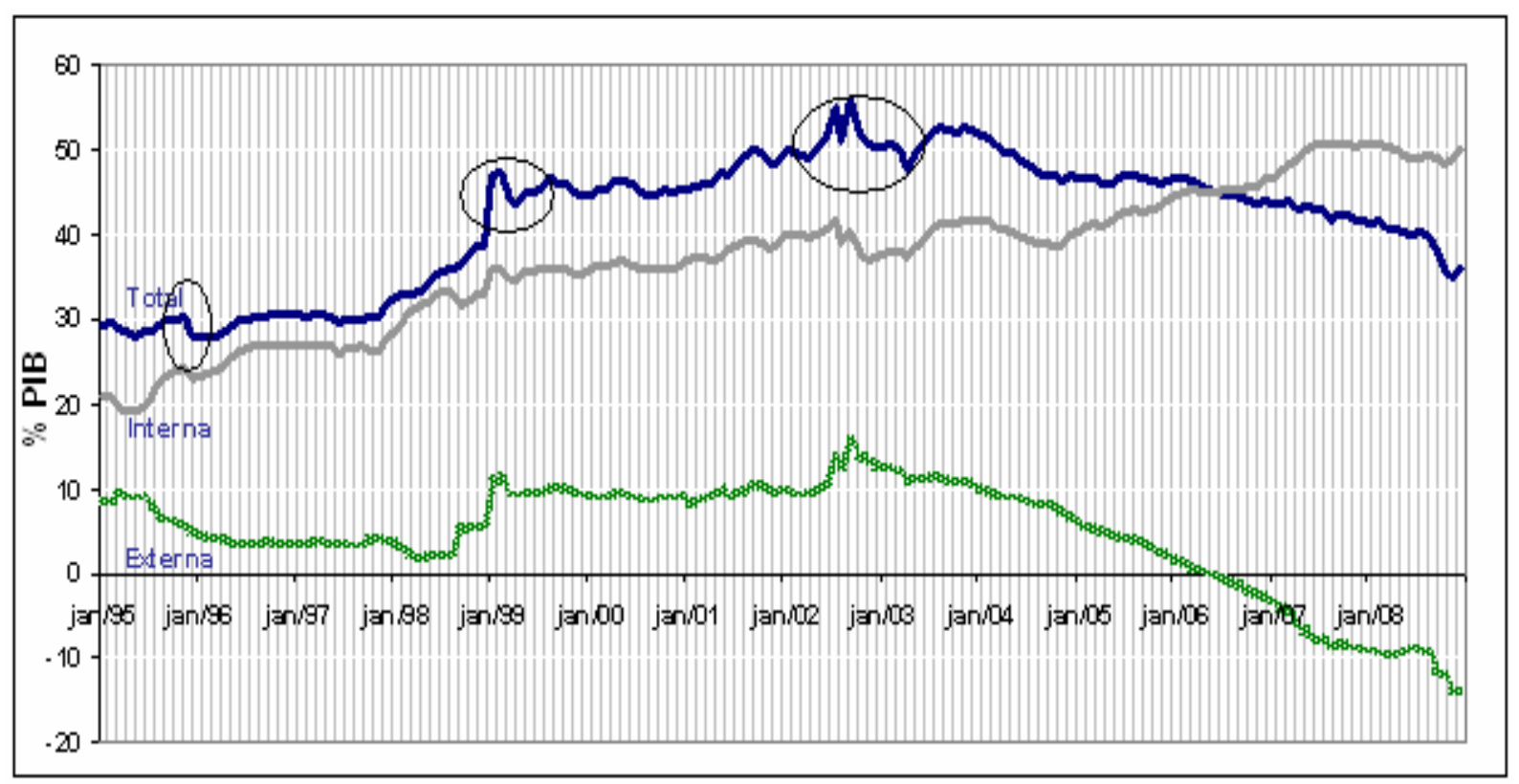

Fonte: Elaborado a partir de séries mensais, de jan/95 a dez/2008, do Banco Central

Já em 2002, com o choque da taxa de câmbio decorrente das incertezas da política econômica do próximo governo, aconteceu o processo inflacionário que promoveu o crescimento nominal da renda e com isso a relação DLSP/PIB foi diminuída.

A partir de 2003 a trajetória da DLSP/PIB começa a reverter, saindo de $52 \%$ em 2003, para 36\% em 2008.

Gráfico 3 - Evolução da Dívida Líquida do Setor Público

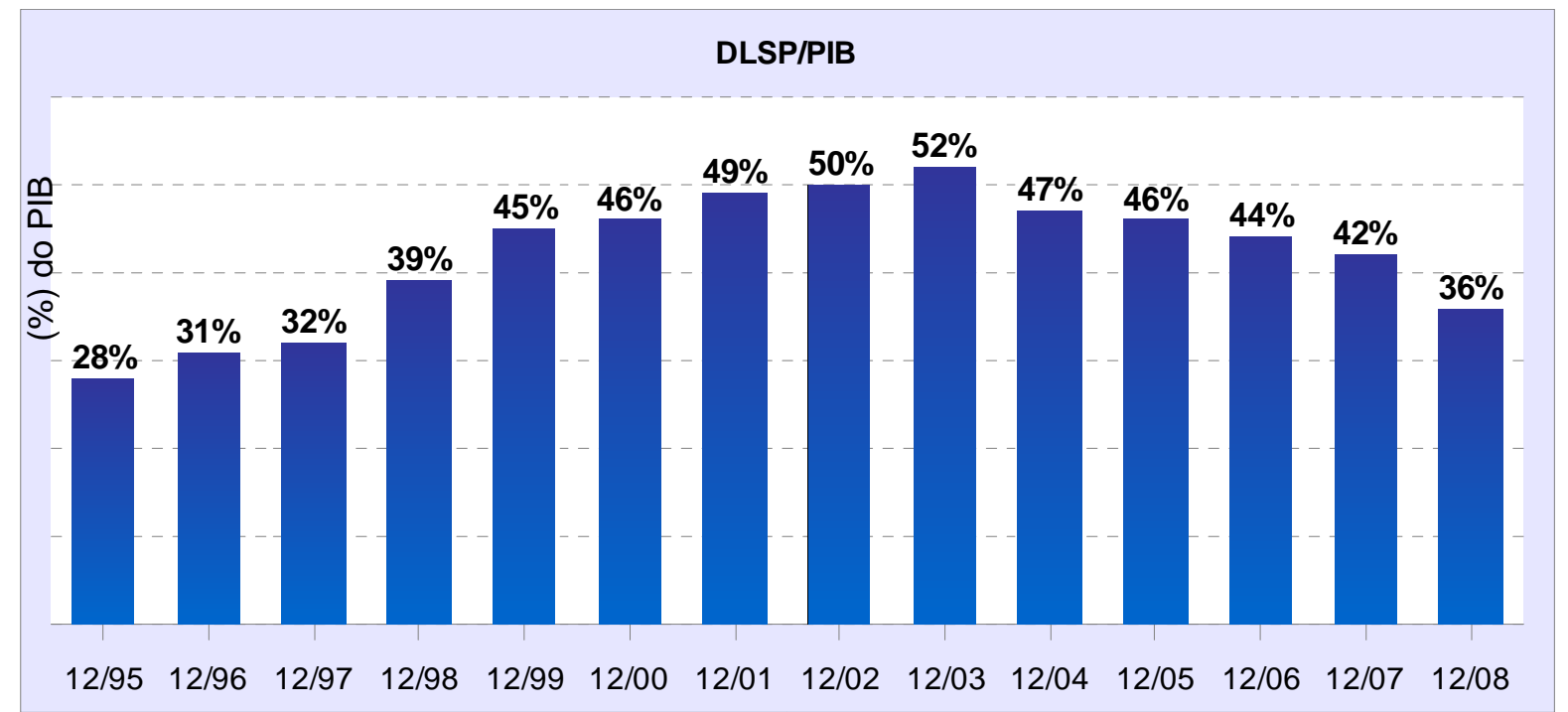

Fonte: Elaborado a partir de dados do Banco Central 
Como o período de 1995 a 2008 envolve duas formas de gestão, convém separá-lo em dois subperíodos para permitir a comparação dos resultados com a gestão empregada.

No período de 1995 a 1998, de acordo com Muntada (2006), a gestão do governo fez uso da política fiscal não restritiva, priorizando a prática de políticas de déficit fiscais. O período foi marcado por uma política de altas taxas de juros como forma de atrair capitais externos e manter a estabilidade cambial. Assim, nesse período, o aumento do endividamento do setor público foi influenciado pelo resultado primário negativo e pela prática de juros altos.

A partir de 1999, o governo mudou de estratégia, promovendo mudanças na política econômica. Introduziu uma política fiscal severa de obtenção de superávits primários como forma de estabilizar a relação DLSP/PIB. Ainda assim não conseguiu estabilizar essa relação, tendo em vista que manteve a prática de elevada taxa de juros, pressionada pela inflação, aliada às pressões sobre a taxa de câmbio.

Diante disso, o governo, por meio do plano anual de financiamento (PAF), reafirmou o comprometimento fiscal estabelecido pela Lei Diretrizes Orçamentárias (LDO), com a definição de metas de superávit primário para serem alcançadas à partir de 2001.

As diretrizes estabelecidas tiveram como objetivo central da gestão da Dívida Pública Federal (DPF) buscando minimizar os custos de financiamento no longo prazo e assegurando a manutenção de níveis prudentes de risco. Assim, a avaliação e o monitoramento permanente da exposição a riscos passaram a ocupar um papel fundamental no planejamento estratégico da dívida pública.

\subsubsection{Evolução da Composição, Custo e Prazo da DLSP}

Para o estudo da evolução da dívida pública, tão importante quanto a avaliação de seus condicionantes é a análise dos demais fatores que a afetam. Há pelo menos três fatores importantes: i) a composição da dívida; ii) a evolução do custo médio; e iii) o prazo médio no período. 
De acordo com Mendonça (2005) são quatro os principais tipos de dívida pública no Brasil, conforme o indexador: taxa de juros (Selic), Índices de preços (IGP e IPCA), câmbio e prefixados. Suas vantagens e desvantagens estão consolidadas no Quadro 1 a seguir.

Quadro 1: Principais indexadores da Dívida Pública Brasileira

\begin{tabular}{|l|l|l|}
\hline Tipo & Vantagens & Desvantagens \\
\hline Índice de Preços & $\begin{array}{l}\text { Sinaliza compromisso com inflação baixa } \\
\text { Permite alongamento }\end{array}$ & Estado absorve risco da inflação \\
\hline Câmbio & $\begin{array}{l}\text { Fornece hedge, evitando aumento da } \\
\text { procura de dólares } \\
\text { Permite alongamento }\end{array}$ & Estado absorve risco do câmbio \\
\hline Selic & Permite alongamento e custos menores & $\begin{array}{l}\text { Política monetária contamina } \\
\text { política fiscal } \\
\text { Política monetária torna-se passiva }\end{array}$ \\
\hline Prefixada & $\begin{array}{l}\text { Isola a Política Fiscal dos choques de } \\
\text { oferta, monetários e externos, tornando a } \\
\text { Política monetária mais eficaz }\end{array}$ & $\begin{array}{l}\text { Usualmente mais custoso. Dificulta } \\
\text { alongamento }\end{array}$ \\
\hline
\end{tabular}

Fonte: Mendonça (2005, p.54)

Nos debates sobre a composição da dívida, tem-se criticado o volume da dívida indexada à taxa Selic. As críticas surgem em razão dessa variável constituir instrumento de controle da inflação e ao tentar conter um choque inflacionário, aumentando-se a taxa Selic, ocorre aumento da dívida pública brasileira.

A esse respeito, Mendonça (2005) argumenta que indexar títulos da dívida em câmbio e Selic não é sempre, em qualquer situação, ruim. Segundo o autor, as críticas são pertinentes, porém deve-se ter em mente que rebalancear a composição dos indexadores da dívida pública não é tarefa fácil e muito menos sem custo.

Com o propósito de melhorar a composição da dívida o Brasil, a partir do ano de 2000, o Tesouro Nacional vem dando preferência pela emissão de papéis prefixados e indexados a índices de preços e buscando reduzir a dívida indexada à taxa cambial e à taxa Selic.

Esses esforços trouxeram mudanças significativas na composição da dívida. Os movimentos de maior representatividade foram a variação da parcela da dívida indexada à taxa cambial e a parcela com taxas prefixadas. 
Em 2001, conforme Gráfico 4 adiante, os papéis indexados à taxa cambial representavam cerca de $40 \%$ da dívida. Contudo houve reduções na sua participação, cedendo lugar aos papéis pré-fixados, que evoluíram de 7\% em 2001 para $40 \%$ em 2007.

Merece destaque também a evolução da parcela indexada a índices de preços, que em 2001 era aproximadamente $9 \%$ e passou para cerca de $30 \%$ em 2007.

Gráfico 4 - Dívida Líquida do Setor Público - Participação percentual por indexador

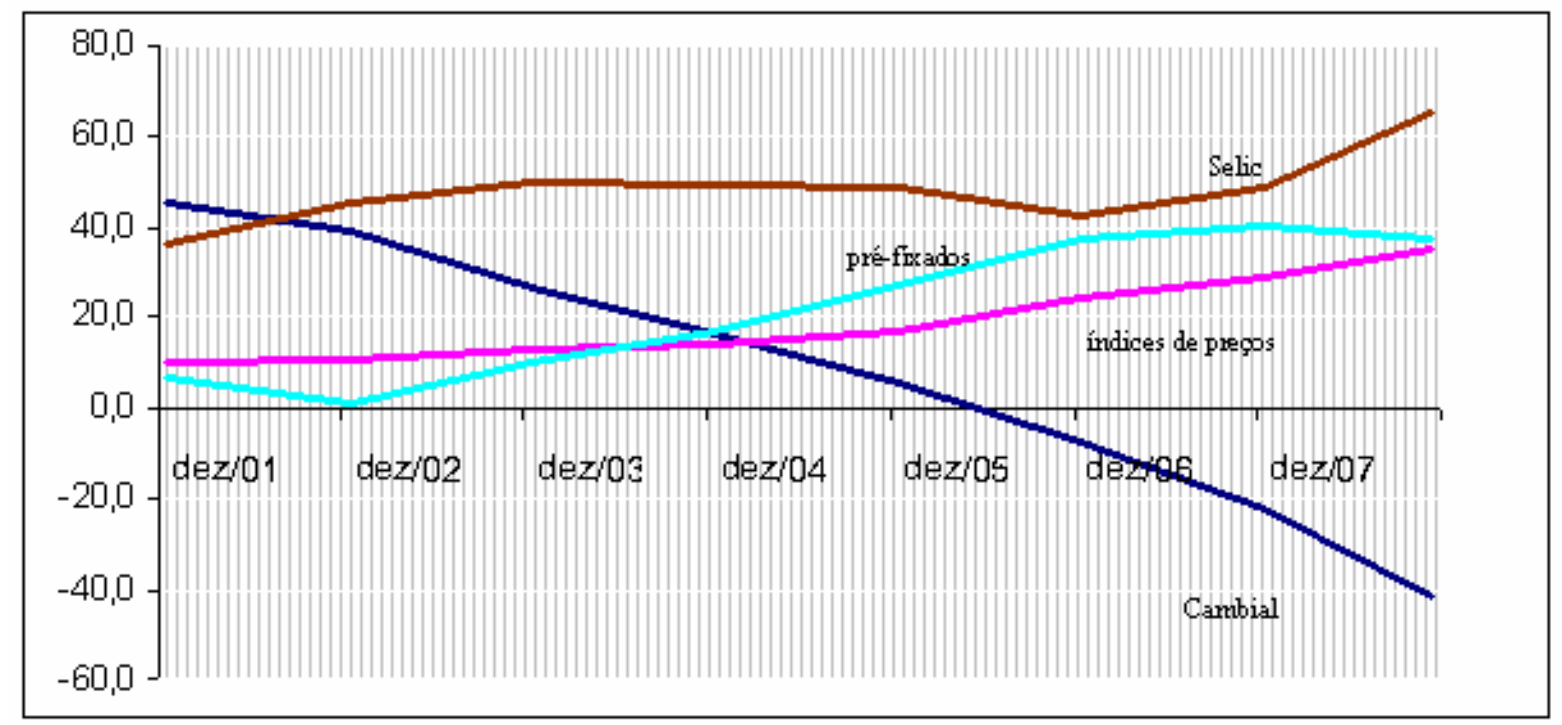

Fonte: Elaborado a partir de dados do Banco Central

A mudança na composição na forma verificada reduziu substancialmente o risco associado à flutuação.

Quanto à parcela da dívida indexada à taxa Selic, a partir de 2003 houve uma redução no percentual de participação, mas a partir de 2007, percebe-se um ligeiro aumento. Em novembro de 2008 a parcela indexada a esse indicador chega a $65 \%$. Parte dessa evolução pode ser explicada pela crise mundial desencadeada nos Estados Unidos, abalando-se a credibilidade doméstica. Isso reforça o que foi dito por Herrera (2002) quando argumenta que no Brasil a indexação constitui um substituto para a credibilidade.

Embora parcela significante da dívida esteja indexada à taxa Selic e, por isso, apresente remuneração mais volátil que a prefixada e que a remunerada por índices de preços, essa parcela tem contribuído para a redução do custo. Isso 
ocorre devido ao processo de redução de taxa de juros e perspectivas que apontam para cenários de queda.

Além da composição e do custo médio, o prazo de vencimentos dos títulos é extremamente relevante para a gestão da dívida, pois quanto mais longos forem, melhor será o gerenciamento, afastando-se a possibilidade de especulações (MENDONÇA, 2005, p.56).

Conforme o Quadro 2, a seguir, o prazo médio teve uma redução a partir de 2003, passando de 39 meses para 33 meses em 2005. Esse encurtamento ocorreu devido ao aumento da participação dos títulos prefixados na composição da dívida brasileira. Percebe-se, no mesmo período um aumento no percentual de títulos vincendos em 12 meses.

A partir de 2005, entretanto, houve avanço no perfil de endividamento, alongando-se o prazo médio de vencimentos e reduzindo-se do percentual vincendo em 12 meses.

Quadro 2: Perfil do Endividamento da Dívida Pública Federal Brasileira

\begin{tabular}{|l|c|c|c|c|c|c|}
\hline Indicadores & Dez/03 & Dez/04 & Dez/05 & Dez/06 & Dez/07 & Dez/08 \\
\hline Estoque da DPF em mercado (R\$ bi) & 965,80 & $1.013,90$ & $1.157,10$ & $1.237,00$ & $1.333,80$ & $1.397,30$ \\
\hline Orazo Médio (meses) & 39,00 & 35,30 & 33,30 & 35,50 & 39,20 & 42,00 \\
\hline \% vincendo em 12 meses & 30,70 & 39,30 & 36,30 & 32,40 & 28,20 & 25,40 \\
\hline
\end{tabular}

Fonte: Secretaria do Tesouro Nacional - PAF

Nota-se que o Tesouro trabalha com a premissa de aumentar a participação de títulos prefixados e remunerados por índices de preços, com redução na participação dos remunerados pela taxa Selic e pela variação cambial.

O objetivo dessa gestão é melhorar o perfil da composição da dívida com vistas a minimizar o custo de financiamento de longo prazo, assegurar níveis prudentes de risco e contribuir para o bom funcionamento do mercado de títulos. Contudo, como foi visto, qualquer alteração na estrutura da dívida envolve custo e prazo.

Nesse contexto, o Tesouro tem a missão de encontrar a melhor forma e momento para promover as mudanças e assim alcançar os seus objetivos de gestão. 


\subsubsection{Sustentabilidade da Dívida Pública}

Tem sido recorrente o debate sobre a sustentabilidade da dívida pública brasileira. Nesse sentido, este item propõe avaliar algumas alternativas de gerenciamento que estão sendo propostas.

Correia e Meurer (2008), argumentam que o debate sobre a dívida pública envolve, antes de tudo, a análise da restrição orçamentária de longo prazo do governo. A restrição, segundo os autores, compreende os valores presentes de toda a evolução de despesas e receitas. Assim, o valor presente dos gastos públicos $(\mathrm{G})$ deve ser menor ou igual à soma da riqueza inicial, ou dívida a pagar (D) mais o valor presente dos tributos a receber, descontados as transferências (T) conforme a equação seguinte:

$$
\int_{t-0}^{\infty} e^{-R(t)} G(t) \leq-D(0)+\int_{t-0}^{\infty} e^{-R(t)} T(t) d t
$$

Outra forma de reescrever a equação da restrição pode ser:

$$
\int_{t-0}^{\infty} e^{-R(t)}[T(t)-G(t)] d t \geq D(0)
$$

A interpretação da equação é que ela indica que o governo tem de obter superávits primários para compensar a dívida inicial. Contudo, para se analisar indicadores fiscais em relação ao endividamento público, deve-se considerar que a redução da taxa de crescimento da dívida ou a sua estabilidade não depende tão somente de uma decisão autônoma do governo, mas também de algumas variáveis determinantes da trajetória da relação Dívida/PIB.

Correia e Meurer (2008) entenderam o conceito de sustentabilidade da dívida pública, admitindo-se a hipótese de que uma política fiscal pode ser considerada sustentável se é possível manter constante a relação entre a dívida líquida do setor público e o PIB.

Assim, dada a restrição orçamentária intertemporal do governo, o controle do endividamento público (relação Dívida/PIB) define o esforço fiscal necessário para que essa relação seja sustentável, considerando o comportamento da taxa de 
crescimento da economia, da taxa de juros e da senhoriagem.

A abordagem de Correia e Meurer (2008) tem como foco a análise da restrição orçamentária, o que permite avaliar a capacidade do devedor em pagar sua dívida.

Uma abordagem mais ampla, que tem como foco a composição, os custos e os prazos da dívida é dada por Llussá (1998) ao analisar a credibilidade da administração da dívida pública no Brasil. Para tanto, examinou três modelos de administração da dívida na literatura econômica.

O primeiro modelo abordado pela autora considera a estrutura de prazos da dívida ótima no contexto de uma economia aberta, com taxas de câmbio fixas, livre movimentação de capitais e onde há um elevado estoque de dívida pública a ser rolada ao longo de todos os períodos.

O modelo descreve alguns problemas diagnosticados numa economia cujas características foram relatadas acima. O principal problema verificado é que na ocorrência de ataque especulativo que ocasione mudanças nas expectativas internas, são necessárias altas taxas de juros para suportar a taxa de câmbio.

Outro problema abordado é que, havendo vencimento de um grande volume de dívida em um momento que não se pode aumentar ainda mais a taxa de juros, o governo poderá ter que optar pelo financiamento mediante a emissão monetária. Com isso os investidores desconfiariam da capacidade do governo em manter a taxa de juros fixa e passariam a exigir taxas nominais ainda maiores.

Assim o modelo propõe, de acordo com a autora, que a melhor maneira de se evitar esse tipo de crise é a mudança no perfil da dívida pública, especificamente alongando os prazos médios dos títulos e distribuindo seus vencimentos uniformemente no tempo.

O segundo modelo estudado trata da questão do risco de uma crise de confiança ou de um default, como determinante do prêmio de risco da dívida. Por isso, defende que a crise de confiança é menor se há emissão apenas de dívida de longo prazo e com vencimentos uniformes em cada período. É considerada também a questão da indexação, ou seja, aumentar a participação de títulos indexados ao índice de preços, para que o passivo do governo torne-se fixo em termos reais e não 
seja vulnerável à política monetária, reduzindo-se assim os custos de se tomar emprestado.

Por fim, a autora analisou o terceiro modelo, que procura estabelecer o impacto e o grau de otimização de diferentes coeficientes de indexação e de estruturas de vencimentos da dívida do governo. Nele, toma-se como restrição uma função de perda social, expressa em termos da carga tributária e do nível de inflação.

É discutida também a possibilidade de a política econômica utilizar a administração da dívida pública como meio de obrigar os governos futuros a cumprirem metas de política fiscal e inflação, garantindo assim, a credibilidade da política econômica.

Enfatizou-se a necessidade de se estabelecer a combinação ótima entre a indexação (títulos indexados ao índice de preços) e o perfil de vencimentos. Quando é possível escolher livremente o grau de indexação e perfil, a política ótima é concentrar toda a dívida em títulos de longo prazo. Em situação contrária, não sendo possível alcançar tal política ótima, o modelo propõe a adoção de um perfil com dívidas de curto prazo.

A análise do terceiro modelo, segundo a autora, sugere que se a indexação for confiável, haverá uma gama de casos em que é ótimo indexar uma parcela da dívida. E quanto ao perfil de vencimentos, o alongamento da dívida seria mais recomendável quanto maior o seu estoque. As simulações do modelo mostram que 0 alongamento é a política mais adequada quando a dívida ultrapassa $50 \%$ do PIB.

De acordo com Llussá (1998) são três as principais vantagens contidas nos modelos de alongamento do perfil do vencimento da dívida pública:

1. Diminuição da probabilidade de ocorrência de uma crise de confiança, evitando, conseqüentemente, a exigência de um prêmio maior pelo risco de default percebido;

2. Alongamento da dívida, com vencimentos distribuídos uniformemente no tempo, o que tende a reduzir os custos da dívida numa situação de crise de confiança; e

3. Alongamento com indexação pode ser utilizado como meio de obrigar 
os governos futuros a cumprirem metas de política fiscal e inflação, garantindo assim a credibilidade da própria política econômica.

Ao estudar a aplicabilidade desses modelos para o Brasil, a autora fez um diagnóstico da situação do país.

$\mathrm{Na}$ década de 1980 a situação econômica fez gerar suscetíveis mudanças na composição da dívida, causando uma instabilidade que se refletiu no perfil do vencimento no Brasil, cujo prazo foi predominantemente de curto prazo.

Essa movimentação de instabilidade e incerteza teve como resultado a deterioração da credibilidade do governo, que se viu obrigado a oferecer prêmios maiores para vender seus títulos. Percebeu-se ainda um movimento cíclico. $O$ grande volume de endividamento exige juros altos e os juros altos leva a maior endividamento.

Foi percebido por Llussá (1998) que havia no Brasil uma demanda potencial por títulos de longo prazo. Mas o público ainda privilegiava a liquidez de curto prazo em razão da memória inflacionária, presença de risco de default e incerteza quanto à consolidação da estabilidade econômica.

Por ocasião da realização do estudo de Llussá (1998), não havia no Brasil a segregação entre política fiscal e monetária, e o Banco Central assumia a função que deveria estar sob a responsabilidade do Tesouro. Além disso, o país encontrava-se em uma fase de baixa credibilidade. Em razão disso, a autora considerava inviável o alongamento da dívida naquele momento, pois seria exigido um prêmio muito elevado para compensar o risco de carregar títulos de longo prazo.

Diferentemente do diagnóstico feito por Llussá, o Brasil passa atualmente por uma fase muito favorável à prática de alongamento do perfil da dívida. Houve a separação das funções do Banco Central e do Tesouro Nacional, cabendo ao Tesouro a emissão, gestão e administração de títulos públicos, a serem utilizados como instrumento de política fiscal e ao Banco Central a responsabilidade pelas operações com títulos públicos em mercado secundário, como instrumento de política monetária.

Outro ponto positivo refere-se à credibilidade em que o país passa na atualidade. Em 2008, o país conquistou o título de "Investiment Grade", que significa grau de investimento, ou seja, uma recomendação de investimento feita por 
agências de risco. Essa confiança ou credibilidade conquistada favorece o alongamento da dívida e possibilita a redução dos custos, ao permitir o pagamento de um prêmio menor aos novos títulos emitidos.

Diferentemente também do período estudado por Llussá é a possibilidade de se aumentar parcela da dívida indexada a índices de preços sem o ônus de custos muito elevados. Como foi argumentado no segundo modelo estudado, essa prática torna o passivo fixo, em termos reais, e menos afetado pela política monetária, contribuindo para a redução dos custos de se tomar emprestado.

\subsection{Fatores Condicionantes da DLSP}

Em Giambiagi e Além (2001), é abordado que a condição de equilíbrio da relação Dívida/PIB envolve a Necessidade de Financiamento do Setor Público (NFSP), as despesas de juros (J) e o superávit primário (SP). Assim:

$$
\mathrm{NFSP}=\mathrm{J}-\mathrm{t}-\mathrm{SP}
$$

Segundo os autores, a NFSP é financiada pela variação da dívida líquida total, excluindo-se a base monetária e a emissão de moeda, representada pela senhoriagem:

$$
\begin{aligned}
& \text { NFSP }=\text { Var. D }-S_{t} \\
& \text { É mostrado também que, para a relação DSLP/PIB ser constante ao }
\end{aligned}
$$
longo do tempo, a taxa de variação nominal do PIB deve ser igual à taxa de variação nominal da DLSP. Com isso, a condição de equilíbrio exigido para que a relação seja estável é que o superávit primário do Setor Público, expresso como proporção do PIB (h) e dada uma certa relação de senhoriagem/PIB, em qualquer período de tempo $(\mathrm{t})$, seja igual a:

$$
h=D \cdot[(1-Y) /(1+Y)]-S
$$


Como mostram Giambiagi e Além, o superávit requerido como proporção do PIB (h) depende diretamente da dívida (D), da taxa de juros (i) e indiretamente do crescimento real da economia $(\mathrm{Y})$ e da senhoriagem (S).

Os autores concluem que, quanto maior a dívida e a taxa de juros, mais o governo necessita se ajustar para obter superávit. Por outro lado, quanto maior o crescimento econômico ou senhoriagem, menor a necessidade de se gerar superávit para a manutenção da dívida constante como proporção do PIB.

\subsubsection{Dívida e Senhoriagem}

A relação DLSP/PIB em 1981, de acordo com Giambiagi e Além (2001), era de 23,7\%, em 1984 essa relação evoluiu para 53\%. Partindo dessa trajetória e considerando que o déficit público era elevado, esperava-se uma trajetória explosiva para o endividamento para a década seguinte.

Contrariando, portanto, essa expectativa, o que se observou foi o uma redução na relação DLSP/PIB a partir de 1987 , caindo de $47,3 \%$ para $27,3 \%$ em 1995.

Silva (2006) contribui para o esclarecimento do fenômeno ao argumentar que durante o processo hiperinflacionário, que durou até meados da década de 1990, o governo utilizava a emissão de moedas como fonte de recursos para financiar o déficit. A esse evento atribui-se o nome de receita de senhoriagem.

Para Giambiagi e Além (2001) o fenômeno se explica pela combinação de déficit e senhoriagem, adicionalmente ao crescimento do PIB.

Além desses fatores, uma outra explicação para a redução da dívida é dada por Rabelo (2008), ao estudar a evolução da dívida no período de 1985-2005. O autor relata que, no Governo Collor, graças ao confisco dos depósitos em poupança e remunerados em conta-corrente, o governo forçou o alongamento da dívida interna e a redução no estoque total da dívida ${ }^{1}$. Essa redução dos ativos

1A abdução dos haveres monetários significou uma diminuição no estoque da dívida entre 90-91, da ordem de $61 \%$ entre $91-92$ da ordem de $16 \%$. 
financeiros da economia, não obstante, somado a um razoável ajuste fiscal, levou o governo a reverter os déficits primários.

Rabelo (2008) esclarece, ainda, que no médio prazo esta situação foi revertida e, na medida em que o Banco Central liberava os novos cruzados retidos, a dinâmica da dívida retomava seu curso explosivo voltando a ter crescimento positivo; de 53\% entre $92-93$ e $40 \%$ entre $93-94$.

\subsubsection{Superávits Primários}

De acordo com Bresser-Pereira (2004), até a década de 1970 o FMI e a ortodoxia convencional cobravam dos países devedores a redução do déficit em conta corrente; a partir de 1980, concentram a atenção no déficit público e, mais recentemente, passaram a preocupar-se apenas com o superávit primário. Tal indicador é útil para os credores por indicar a disponibilidade de recurso para o país pagar juros.

À medida que a dívida cresce, o resultado primário tem de aumentar para indicar aos investidores que o governo está disposto e será capaz de pagar as obrigações futuras do serviço da dívida. (HERRERA, 2002).

Gráfico 5 - Resultado Primário do Setor Público Consolidado

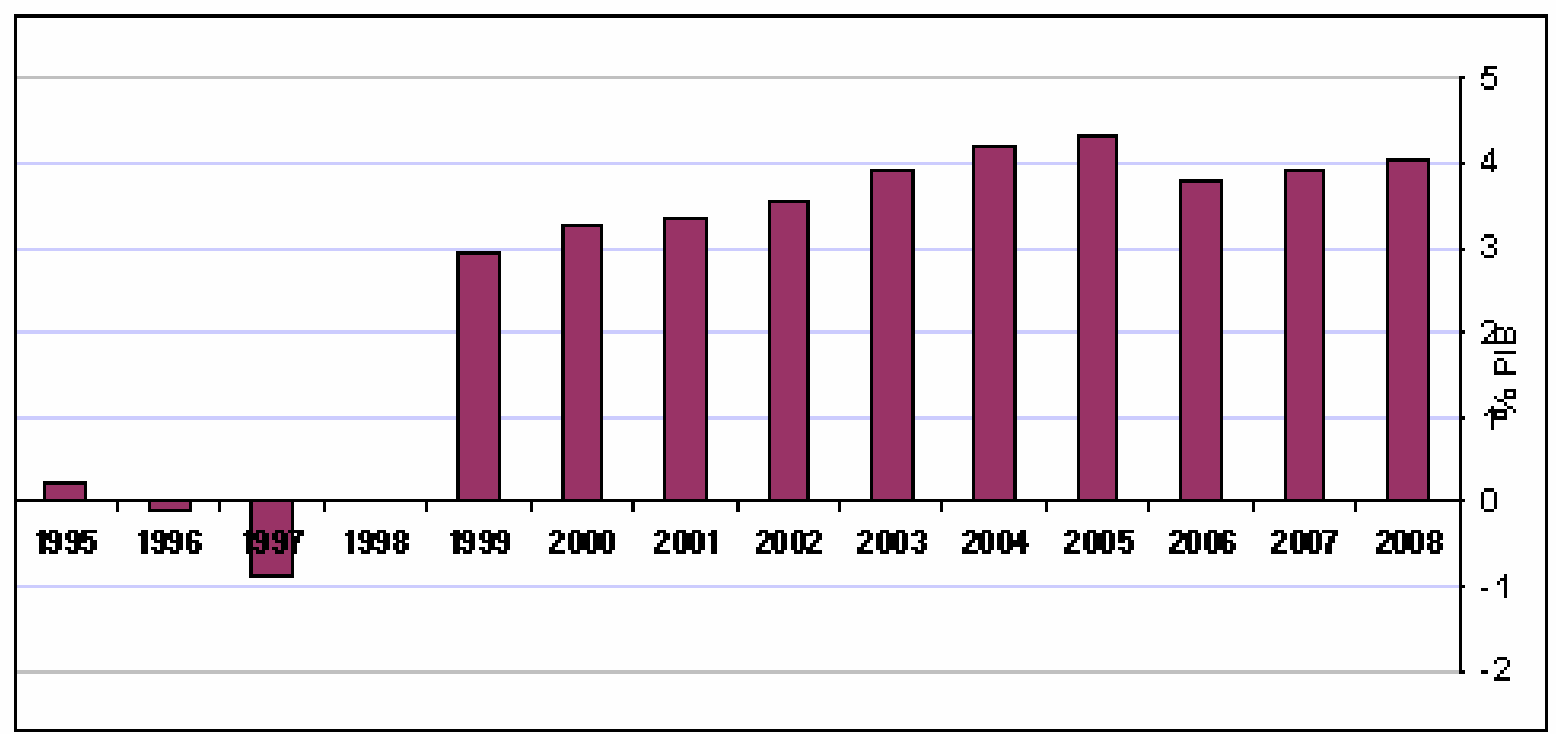

Fonte: Elaborado a partir de dados do Banco Central 
Conforme mostra $\circ$ Gráfico 5, após o estabelecimento de meta para o superávit primário como forma de reverter à situação, o Brasil obteve superávits entre 3\% e 5\% a partir de 1999. A geração de superávits primários é, de acordo com Silva (2006), condição fundamental para se assegurar a trajetória declinante da relação DLSP/PIB.

Para Bresser-Pereira e Ribeiro (2008), o superávit primário, embora em voga atualmente, não parece ser a medida mais adequada para avaliar a situação fiscal de um país, por excluir de seu cálculo o pagamento dos juros da dívida pública. Dessa forma, mesmo com superávit primário da ordem de $5 \%$, a economia pode ter uma poupança pública negativa.

A despeito disso, os autores defendem a importância da poupança pública para o desenvolvimento econômico, que, ao excluir de seu cálculo os investimentos promovidos pelo governo, diferencia-se plenamente das outras variáveis públicas utilizadas para se avaliar a situação fiscal de uma esfera de governo, marcadamente as mencionadas medidas de superávits.

Da mesma forma, Herrera (2002) argumenta que a poupança pública é fundamental para o desenvolvimento econômico, pois indica a capacidade de financiamento dos investimentos, especialmente os investimentos em infra-estrutura que o setor privado não tem interesse em realizar, e os investimentos de segurança. Se a poupança pública aproxima-se de zero, a realização desses investimentos dáse apenas por meio do déficit público. Por outro lado, para se reduzir o déficit público e maximizar o superávit primário, a solução é reduzir os investimentos.

$\mathrm{Na}$ ocorrência de poupança pública negativa, segundo Herrera (2002), mesmo não havendo investimentos, ocorre déficit público para financiar parte dos gastos correntes. Com isso, verifica-se a importância que a poupança pública tem na política fiscal. Justifica-se assim a idéia de se acrescentar aos objetivos de política econômica o objetivo de poupança.

Esse é também o entendimento de Bresser-Pereira (2004), ao defender que o superávit primário (ou déficit público) planejado não deve ser alcançado simplesmente reduzindo-se os investimentos públicos, como tem acontecido no Brasil desde a crise da década de 1980. 
Em seu estudo, Muntada (2006) admitiu como hipótese básica que o superávit primário, estabelecido pelo governo como forma de estabilizar a dívida, é alcançado mais em função do aumento das receitas que da redução da despesa.

\subsubsection{Efeitos da Composição da DLSP}

A dívida pública brasileira tem três características. Em primeiro lugar é principalmente doméstica, com a proporção da dívida interna para a externa da ordem de 4:1; em segundo lugar, tem curta maturidade e duração; e em terceiro, sua composição mostra que grande parte dela é indexada (HERRERA, 2002, p.11).

Giambiagi e Além (2001) fizeram uma análise da relação dívida/PIB, para o ano de 1999, utilizando como referência 15 países que formam a União Européia e mais alguns países de "economias emergentes".

Discutiu-se que de um modo geral a relação dívida/PIB dos países avaliados são maiores que no Brasil. Contudo, realçou-se a importância da composição e do custo da dívida.

Em relação à composição, foi observado que, em geral, os países mais avançados e com uma dívida maior que a brasileira costumam ter um mercado de títulos suficientemente desenvolvido, combinado com longa tradição de estabilidade, o que Ihes permite ter uma proporção elevada da dívida na forma de papéis de longo prazo de maturação e com taxas pré-fixadas.

Vale associar que, com essa composição, em caso de crise, havendo necessidade de aumentar os juros, o país se defronta com uma necessidade de rolagem relativamente confortável. Dessa forma, o movimento de alta de juros afetaria apenas uma pequena fração da dívida, que seria representada pelos novos papéis emitidos.

Em regra oposta, caso o país possua dívidas de curto prazo e volume considerável de dívida indexada, fica sujeito às oscilações de mercado e sofre impactos significativos na ocorrência de aumento de taxas de juros.

No que se refere ao custo do financiamento, foi apresentado o caso da Itália. Embora ela apresente uma dívida superior a 100\% do PIB, no ano de 2000 a 
Itália pagou pela sua dívida uma taxa nominal de cerca de $5 \%$. No Brasil, por sua vez, embora a relação dívida/PIB tenha se apresentado substancialmente inferior, o governo pagou taxa de juros significativamente maior.

Abordagem semelhante foi feita por Herrera (2002), ao examinar a relação dos pagamentos de juros como proporção do PIB entre vários países, percebendo uma tendência nos países que têm grandes pagamentos de juros a ter maior superávit primário.

Figura 1 - Pagamento de juros e Resultado Primário

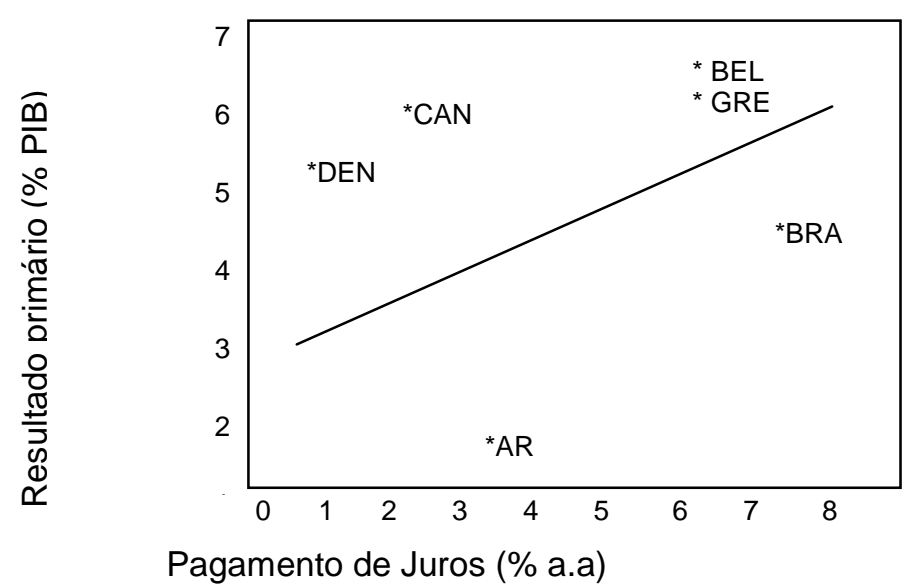

Fonte: Herrera (2002, p.17). Dados referente a 2001

Nota: Dinamarca (DEN), Canada (CEN), Bélgica (BEL), Grécia (GRE), Brasil (BRA) e Argentina (AR)

Considerando o padrão internacional, apresentado na Figura 1,0 resultado primário do Brasil estaria bem abaixo do padrão analisado. Enquanto no Brasil o gasto com juros da dívida foi de 7,3\% do PIB, em 2001, a Grécia, Bélgica e Itália tiveram pagamentos de juros semelhantes e registraram superávits primários na faixa de $4,5 \%$ a $6 \%$ do PIB.

O pagamento de juros altos pelo Brasil pode ser explicado pelo volume da dívida indexada à taxa básica de juros (Selic), conforme apresentado no item 2.1.4.

Em Herrera (2002), argumenta-se que até 1997, quando a relação Dívida/PIB era relativamente estável, mais de $40 \%$ da dívida interna era composta por obrigações de taxa fixa. À medida que a economia se estabilizava essa parcela foi diminuindo. 
Essa relação negativa entre tamanho da dívida e obrigações com taxa fixa não é, de acordo com o autor, exclusiva do Brasil. Quanto maior a dívida, maior o risco de crédito. Conseqüentemente as exigências de retorno e, no caso do Brasil, a indexação constituiu um substituto para a credibilidade.

Gráfico 6 - Composição da Dívida Líquida do Setor Público

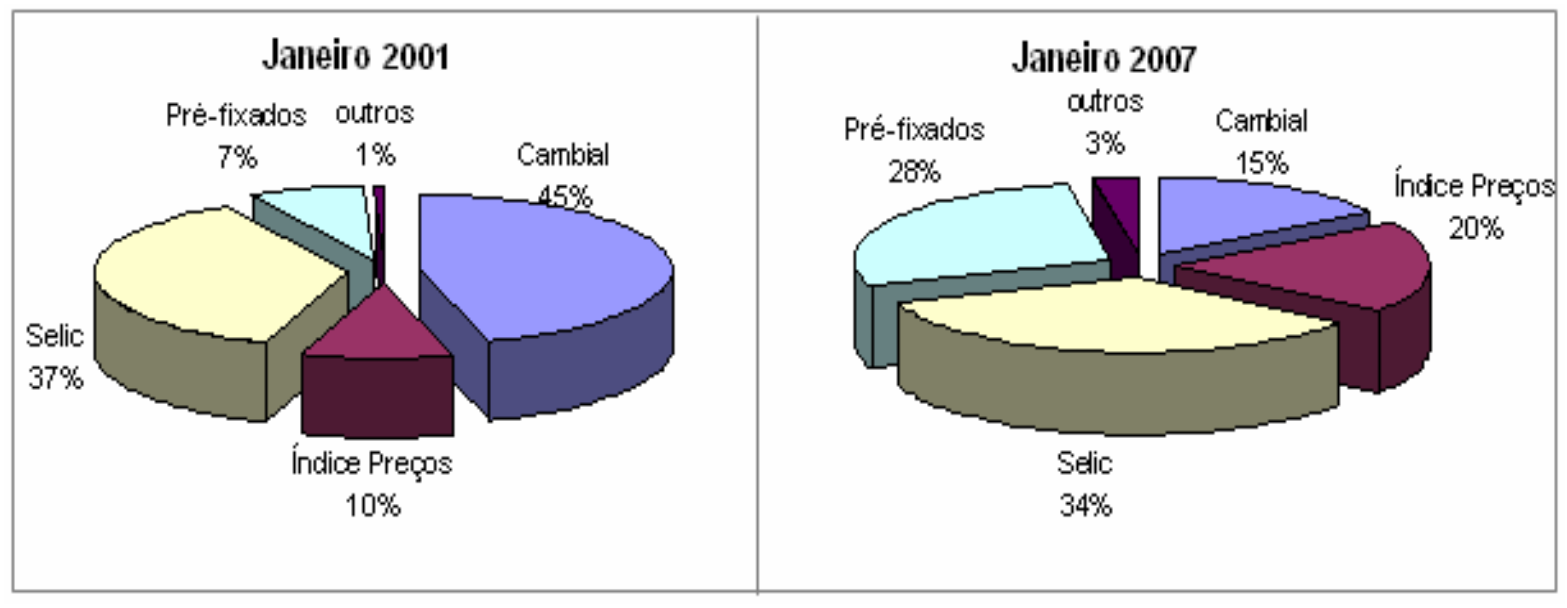

Fonte: Elaborado a partir de dados do Banco Central

No Gráfico 6 percebe-se que de janeiro de 2001 a janeiro de 2007 houve uma pequena redução na parcela da dívida indexada a taxa Selic. Contudo, ela ainda representa a maior parcela.

Em razão dessa composição, a medida de política econômica que utiliza a manutenção dos juros como forma de cumprir as metas de inflação traz um efeito direto no custo do financiamento da dívida, elevando a relação Dívida/PIB. Muntada (2006) argumenta que esse comportamento obriga o governo a administrar o perfil da dívida, com o objetivo de controlar seus custos.

O autor atribui também como fator contribuinte ao endividamento público, principalmente a partir de 1999, a dívida atrelada à taxa de câmbio.

Para Benecke (2002) a melhor medida que causa menores custos para a população é uma política fiscal equilibrada e um sistema tributário que incentiva os investimentos e a produção. 


\subsubsection{Dívida Líquida do Setor Público e o Crescimento Econômico (PIB)}

A análise do Gráfico 7, seguinte, nos permite constatar que o crescimento do PIB a partir de 2004 foi superior à evolução da DLSP. Como nesse período não se percebe reduções substanciais nos gastos públicos, o crescimento do PIB pode ter contribuído para a trajetória de queda verificada a partir de 2004.

Gráfico 7 - Evolução da Dívida Líquida Setor Público e PIB

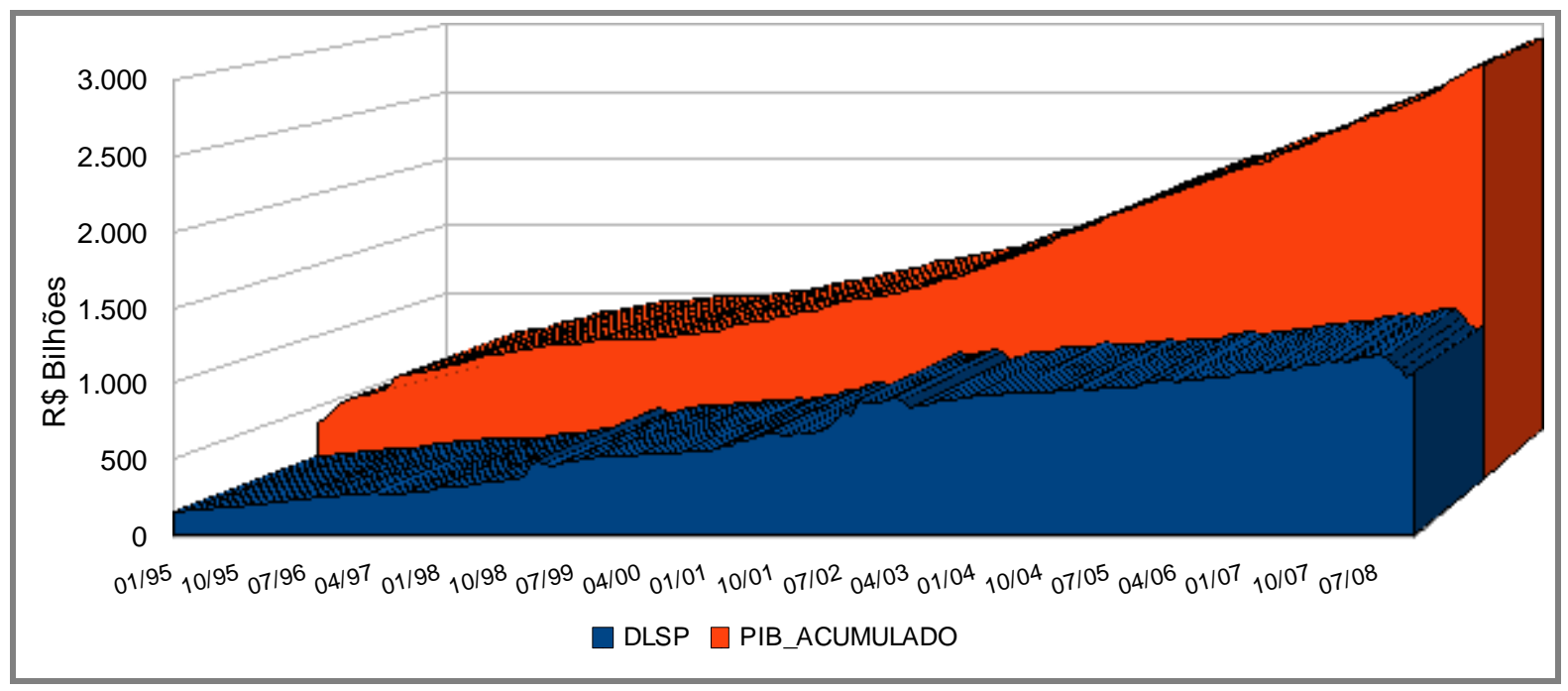

Fonte: Elaborado a partir de dados do Banco Central

Goldfajn (2002), em nota técnica emitida pelo Banco central, realizou estudo para o período de 2002 a 2011 simulando a variação da relação dívida/PIB dado à evolução do PIB. Segundo o autor, com o crescimento potencial do PIB da ordem de $4,5 \%$ a relação dívida/PIB tenderia a cair consideravelmente. No cenário básico, com o PIB de 3,5\%, era esperada uma queda na relação dívida/PIB. Uma menor taxa de crescimento do PIB, de 2,4\% a partir de 2003, não causaria o aumento da relação dívida/PIB ao longo do tempo. Para o autor, mesmo esse baixo nível de crescimento seria consistente com uma relação declinante após alguns anos.

No Gráfico 8 a seguir consta a representação da evolução da DLSP/PIB com a simulação, considerando o crescimento do PIB de 2,4\%, 3,5\% (cenário básico) e $4,5 \%$. 
Gráfico 8- Dívida Líquida do Setor Público, 2002-2011

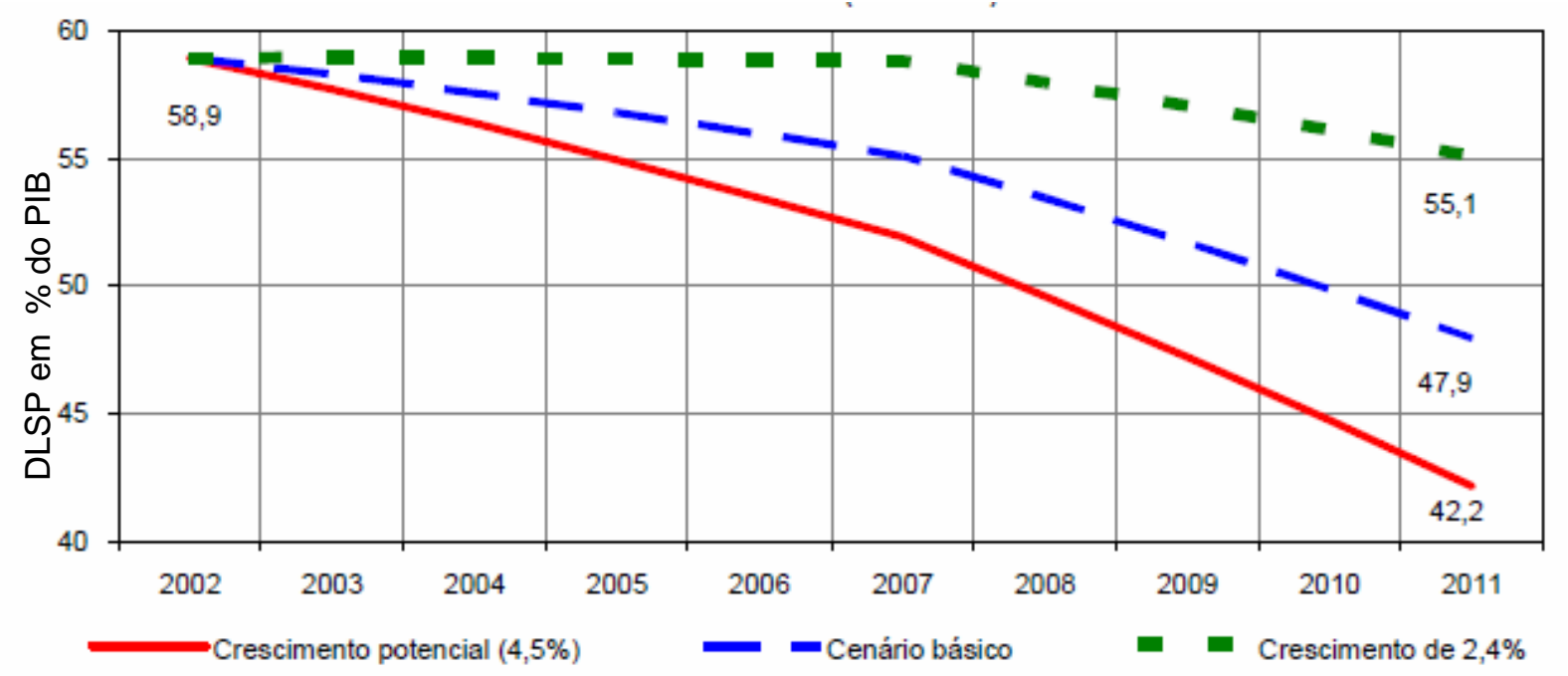

Fonte: Goldfajn (2002, p.18). Exercícios com taxas de crescimento (\%PIB).

De acordo com o Gráfico 8, considerando um PIB em torno de 4,5\% era esperada para 2007 a relação DLSP/PIB acima de 50\%. Contudo, essa relação foi caindo chegando próximo aos 40\% em 2007.

Essa diferença pode ser explicada pelo crescimento médio do PIB no período 2004-2008 ter sido maior que os 4,5\% projetado, conforme Gráfico 9, e também pela geração de superávit primário, que reduziu a necessidade de financiamento no período.

Gráfico 9- Taxa de variação real do PIB (\%)

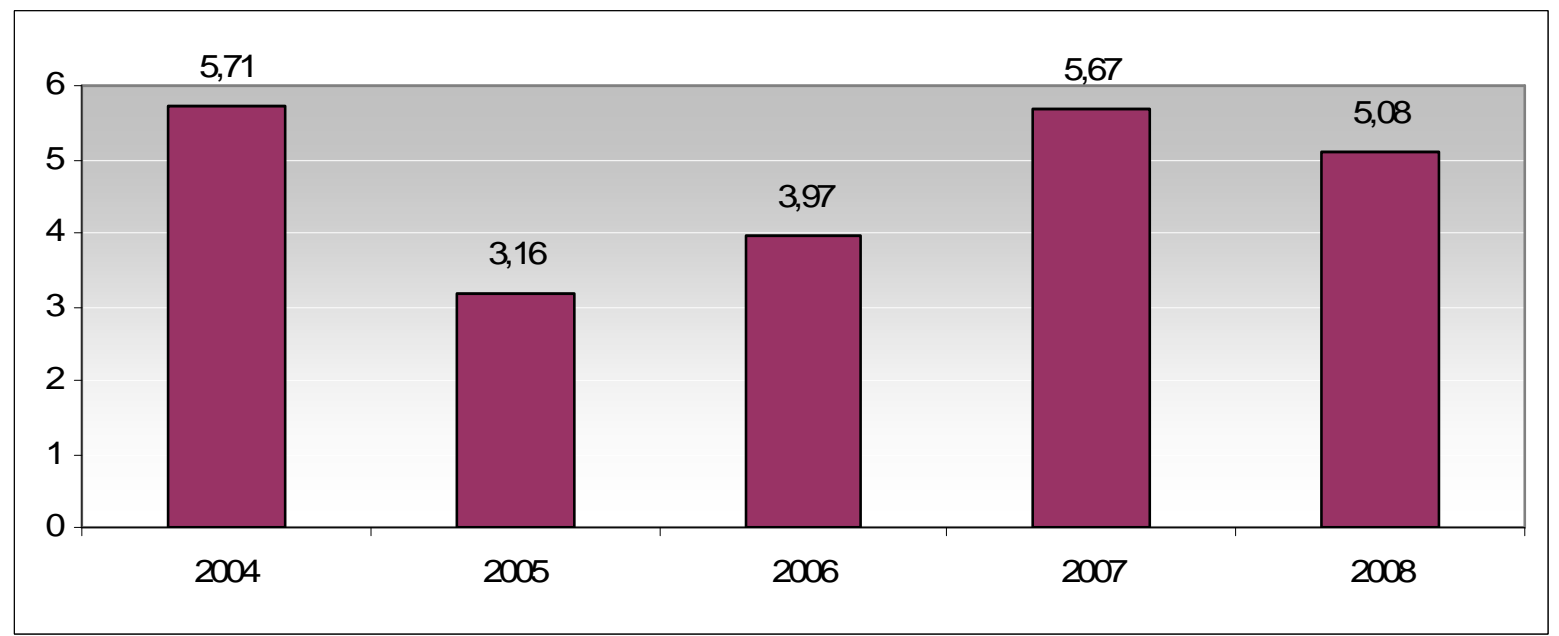

Fonte: Elaborado a partir de dados do Banco Central do Brasil 


\section{OS NÚMEROS DO BANCO CENTRAL}

O Banco Central realizou análise dos fatores condicionantes da evolução da dívida pública líquida para o período de 1996 a 2008, conforme Quadros 3 e 4 apresentados a seguir:

Quadro 3 - Fatores condicionantes da Evolução da Dívida Líquida (1996-2001)

\begin{tabular}{|c|c|c|c|c|c|c|}
\hline & 1996 & 1997 & 1998 & 1999 & 2000 & 2001 \\
\hline Dívida líquida total - saldo & 30,7 & 31,8 & 38,9 & 44,5 & 45,5 & 48,4 \\
\hline Dívida líquida - var. ac. ano & 2,7 & 1,1 & 7,1 & 5,6 & 1,0 & 2,9 \\
\hline Fatores condicionantes: ${ }^{1 /}$ & 6,9 & 4,0 & 7,8 & 11,3 & 3,8 & 7,2 \\
\hline NFSP & 5,1 & 5,3 & 6,9 & 4,9 & 3,2 & 3,1 \\
\hline Primário & 0,1 & 0,9 & 0,0 & $-2,7$ & $-3,1$ & $-3,2$ \\
\hline Juros nominais & 5,0 & 4,5 & 6,9 & 7,5 & 6,3 & 6,3 \\
\hline Ajuste cambial & 0,2 & 0,4 & 0,7 & 6,0 & 1,5 & 2,3 \\
\hline $\begin{array}{l}\text { Dívida mobiliária interna indexada ao } \\
\text { câmbio }\end{array}$ & 0,1 & 0,2 & 0,4 & 3,4 & 0,8 & 1,4 \\
\hline Dívida externa - metodológico & 0,1 & 0,3 & 0,3 & 2,5 & 0,7 & 0,9 \\
\hline Dívida externa - outros ajustes ${ }^{2 /}$ & 0,0 & 0,0 & 0,0 & 0,0 & 0,0 & 0,0 \\
\hline Reconhecimento de dívidas & 1,7 & 0,0 & 1,5 & 1,2 & 0,7 & 1,9 \\
\hline Privatizações & $-0,1$ & $-1,7$ & $-1,3$ & $-0,8$ & $-1,6$ & $-0,1$ \\
\hline $\begin{array}{l}\text { Efeito do crescimento do PIB sobre a } \\
\text { dívida }^{3 /}\end{array}$ & $-4,2$ & $-2,9$ & $-0,7$ & $-5,7$ & $-2,8$ & $-4,3$ \\
\hline
\end{tabular}

Fonte: Focus: Banco Central 
Quadro 4 - Fatores condicionantes da Evolução da Dívida Líquida (2002-2008)

\begin{tabular}{|c|c|c|c|c|c|c|c|}
\hline & 2002 & 2003 & 2004 & 2005 & 2006 & 2007 & 2008 \\
\hline Dívida líquida total - saldo & 50,5 & 52,4 & 47,0 & 46,5 & 44,0 & 42,0 & 36,0 \\
\hline Dívida líquida - var. ac. ano & 2,0 & 1,9 & $-5,4$ & $-0,5$ & $-2,4$ & $-2,0$ & $-6,0$ \\
\hline Fatores condicionantes: ${ }^{1 /}$ & 12,6 & 1,8 & 2,2 & 2,1 & 2,7 & 3,0 & $-2,7$ \\
\hline NFSP & 3,5 & 4,5 & 2,3 & 2,9 & 2,9 & 2,1 & 1,5 \\
\hline Primário & $-3,0$ & $-3,8$ & $-4,0$ & $-4,3$ & $-3,7$ & $-3,7$ & $-4,0$ \\
\hline Juros nominais & 6,5 & 8,3 & 6,3 & 7,3 & 6,6 & 5,8 & 5,5 \\
\hline Ajuste cambial & 8,4 & $-3,7$ & $-0,8$ & $-0,8$ & $-0,2$ & 1,1 & $-3,3$ \\
\hline Dívida móbil. interna index. câmbio & 4,4 & $-1,3$ & $-0,2$ & $-0,2$ & $-0,1$ & $-0,1$ & 0,1 \\
\hline Dívida externa - metodológico & 4,0 & $-2,4$ & $-0,6$ & $-0,6$ & $-0,1$ & 1,2 & $-3,4$ \\
\hline Dívida externa - outros ajustes ${ }^{2 /}$ & 0,0 & 1,0 & 0,4 & $-0,1$ & 0,1 & $-0,1$ & $-0,9$ \\
\hline Reconhecimento de dívidas & 0,8 & 0,0 & 0,3 & 0,2 & 0,0 & 0,0 & 0,0 \\
\hline Privatizações & $-0,2$ & 0,0 & 0,0 & 0,0 & $-0,1$ & 0,0 & 0,0 \\
\hline $\begin{array}{l}\text { Efeito do crescimento do PIB sobre a } \\
\text { dívida }^{3 /}\end{array}$ & $-10,6$ & 0,0 & $-7,5$ & $-2,6$ & $-5,1$ & $-5,0$ & $-3,3$ \\
\hline
\end{tabular}

Fonte: Focus: Banco Central

Nos Quadros 3 e 4 percebe-se que os juros nominais são responsáveis por grande parte da variação da relação DLSP sobre o PIB, acumulando um impacto de 82,9 pontos no período.

Esse dado confirma a hipótese de que a taxa de juros responde por grande parte da evolução do endividamento brasileiro. E por assim enxergarem, alguns autores argumentam que o programa de redução da dívida deveria se concentrar na redução dos juros e não na contenção dos gastos ordinários do Tesouro.

Destaca-se também o efeito do crescimento do PIB na redução da DLSP/PIB, com o impacto de $-54,7$ pontos até 2008.

Embora em proporção menor, porém com efeitos substantivos sobre a dívida, tem-se da depreciação cambial, que acumulou impacto no período 9,0 pontos percentuais para mais.

Cabe também citar a participação decorrente do reconhecimento de dívidas passadas, os "esqueletos", que responderam por um aumento em torno de 8,0 pontos percentuais e as privatizações ocorridas, que contribuíram com cerca de 6,0 pontos para a redução da DLSP/PIB. 


\section{METODOLOGIA}

O estudo trata-se de uma pesquisa empírica documental quantitativa, podendo ainda ser classificada quanto aos fins, de acordo com a metodologia proposta por Vergara (2000), como pesquisa que utiliza a investigação explicativa.

No estudo, realizou-se uma análise empírica com a finalidade de investigar a contribuição das variáveis condicionantes da dívida pública na sua evolução.

\subsection{Amostra de dados}

Para a definição da amostra utilizou-se o critério de tipicidade proposto por Vergara (2000), em que a amostra é constituída dos elementos representativos para o estudo. Neste caso, optou-se pela utilização dos fatores condicionantes da dívida pública, tomando-se como base os números informados pelo Banco Central.

A amostra é então composta pela taxa de câmbio, pela taxa de juros reais, pelo superávit primário, pelo produto interno bruto valorizado e pela Dívida Líquida do Setor Público.

Para mensurar a taxa de câmbio, optou-se pela utilização da taxa de câmbio - efetiva real - INPC - exportações - índice (média $2000=100$ ), obtida no IPEA/DATA ${ }^{2}$. Aplicou-se o log para tornar a série mais uniforme. Em razão da quebra estrutural decorrente da mudança da política cambial que passou a ser flutuante a partir de 1999, utilizou-se uma variável auxiliar para linearizar a série.

A taxa de juros reais foi obtida descontando da taxa de juros básica

2 Calculada pela medida da competitividade das exportações brasileiras calculadas pela média ponderada do índice de paridade do poder de compra dos 16 maiores parceiros comerciais do Brasil. A paridade é definida pelo quociente entre a taxa de câmbio nominal (em $R \$$ /unidade de moeda estrangeira) e a relação entre o Indice de Preço por Atacado (IPA) do pais em caso e o Indice Nacional de Preços ao Consumidor (INPC/IBGE) do Brasil. As ponderações utilizadas são as participações de cada parceiro no total das exportações brasileiras em 2001. 
(SELIC) o índice de inflação medido pelo IPCA. A fonte de dados é do Banco Central do Brasil.

Para representar o superávit primário, foi escolhida a série referente à Necessidade de Financiamento do Setor Público (NFSP) no conceito primário, que representa o esforço fiscal empregado pelo governo para reduzir a necessidade de financiamentos, e portanto, o endividamento. Os dados são disponibilizados pelo Banco Central do Brasil.

Para mensurar o crescimento econômico, utilizou-se o Produto Interno Bruto Valorizado - acumulado 12 meses, disponibilizado pelo Banco Central. À série foi aplicado o logaritmo para linearização.

Para mensurar a Dívida Líquida do Setor Público, optou-se pela utilização da série expressa em valores correntes. A série DLSP expressa em percentual do PIB foi preterida em razão desta série expurgar os efeitos do crescimento econômico na evolução da dívida. A fonte de dados foi do Banco Central do Brasil. Sob os dados aplicou-se o logaritmo para linearização.

As séries têm periodicidade mensal e compreende o período de 1995 até 2008.

\subsection{Instrumentos e Procedimentos}

O estudo foi realizado para o período de janeiro de 1995 a dezembro de 2008. Contudo, avaliou-se o período em duas etapas. Na primeira, foi analisada a evolução dos indicadores considerando o período total. Já na segunda, foi avaliado o período a partir de 1999. Optou-se pela realização das duas análises em razão da quebra estrutural verificada a partir de 1999, fazendo-se uma comparação entre as políticas adotadas e os resultados obtidos nos períodos.

Conforme argumentação de Herrera (2002), o peso da dívida é alto porque as taxas de juros reais são altas e, por sua vez, as taxas de juros são altas devido à preocupação com a sustentabilidade das finanças públicas. Para romper o círculo vicioso ou deflagrar um espiral virtuoso de redução da dívidadiminuição das taxas de juros-crescimento maior, as autoridades econômicas 
devem decidir qual é a variável mais exógena sob a qual pode exercer maior controle.

Diante disso, a análise das informações envolveu procedimentos estatísticos propostos por Bueno (2008). Segundo o autor, é fundamentalmente a constatação de estacionariedade que permite proceder às inferências estatísticas. Resumidamente, uma série é considerada estacionária quando ela flutua em torno de uma média fixa e se a variância é constante ao longo do tempo.

Como a inspeção visual de uma série raramente permite distingui-la como estacionária ou não, podendo incorrer em equívocos, foi utilizado o teste de raiz unitária Dickey-Fuller Aumentado (ADF).

Aplicou-se o teste de co-integração de Johansen. Esse teste permitiu verificar se existe equilíbrio, ou relacionamento, de longo prazo entre as variáveis econômicas, indicando o número de vetores de co-integração.

Depois de aplicado o teste, foi estimado o modelo de Vetor AutoRegressivo - VAR nas séries estacionárias. O VAR permite que se expressem modelos econômicos completos e se estimem os parâmetros desse modelo.

Adicionalmente foi utilizado o teste de Granger-Causalidade. De acordo com Bueno (2008), a questão fundamental desse teste é saber se o escalar de uma variável ajuda a prever o escalar de outra. A partir desse teste, utilizou-se a estatística Qui-Quadrada para identificar o ordenamento correto das variáveis.

Uma análise complementar foi realizada, utilizando-se da decomposição da variância. Com esse procedimento, checou-se a porcentagem da variância do erro de previsão decorrente de cada variável endógena ao longo do horizonte de previsão.

Os procedimentos estatísticos descritos permitiram avaliar a influência da evolução das variáveis condicionantes sobre a evolução da dívida líquida do setor público (DLSP).

O software estatístico utilizado para a realização os procedimentos mencionados foi o software livre R-Project. 


\section{RESULTADOS}

Nesta seção serão apresentados os resultados obtidos para os procedimentos estatísticos descritos na seção anterior. Primeiramente serão apresentados os testes de estacionariedade. Em seguida será apresentado o teste de co-integração e, por fim, têm-se o modelo VAR com a função impulso resposta e a decomposição da variância.

\subsection{Teste de Estacionariedade}

Para a realização dos testes de estacionariedade, empregou-se o teste Dickey-Fuller Aumentado-ADF. Os resultados são apresentados no quadro seguinte:

Quadro 5 - Resultados para os testes de estacionariedade - ADF

\begin{tabular}{|l|r|r|r|r|r|}
\hline Variável & \multicolumn{1}{c|}{ Ipib } & \multicolumn{1}{c|}{ Idlsp } & \multicolumn{1}{c|}{ dcambio } & jurosreais & \multicolumn{1}{c|}{ rp } \\
\hline Teste ADF & $-4,76$ & $-3,91$ & $-2,08$ & $-5,34$ & $-2,36$ \\
\hline Defasagens & 1 & 1 & 1 & 1 & 12 \\
\hline Valor Crítico & $-3,43$ & $-2,88$ & $-1,95$ & $-3,43$ & $-1,95$ \\
\hline
\end{tabular}

Os resultados apresentados no Quadros 5 apontam para estacionariedade em todas as séries avaliadas. Assim, seguiu-se com o teste de cointegração, para verificar se as séries possuem relação de longo prazo.

\subsection{Teste de co-integração de Johansen}

Com esse teste é verificado se existe relacionamento de longo prazo entre as variáveis econômicas estudadas. $O$ teste de Johansen permite identificar quantos vetores de co-integração existem entre as variáveis. 
Quadro 6 - Resultados para os teste de cointegração sem traço

\begin{tabular}{|l|c|c|l|}
\hline Vetor & test & $5 p c t$ & \multicolumn{1}{|c|}{ resultado } \\
\hline$r<=4$ & 4,91 & 9,24 & não rejeita \\
\hline$r<=3$ & 19,71 & 19,96 & não rejeita \\
\hline$r<=2$ & 36,77 & 34,91 & rejeita \\
\hline$r<=1$ & 93,37 & 53,12 & rejeita \\
\hline$r=0$ & 152,11 & 76,07 & rejeita \\
\hline
\end{tabular}

De acordo com os resultados do Quadro 6, rejeita-se as hipóteses para zero, um e dois vetores e não se rejeita as hipóteses para três e quatro vetores. Assim as séries analisadas são co-integradas com pelo menos três vetores de co-integração. O teste com traço também aponta para três vetores de co-integração.

\subsection{Modelo VAR para Dívida Líquida do Setor Público - 1995 à 2008}

Após a confirmação de co-integração entre as séries, empregou-se o VAR para não perder informações com a utilização de modelos univariados.

Os testes utilizados para indicar a quantidade ótima de defasagens para o modelo indicaram que devem ser utilizadas duas defasagens.

Quadro 7 - Critério de Seleção da Defasagem do VAR

\begin{tabular}{|r|r|r|r|r|}
\hline № Defasagem & \multicolumn{1}{c|}{ AIC(n) } & HQ(n) & \multicolumn{1}{c|}{ SC(n) } & FPE(n) \\
\hline 1 & 1,15 & 1,37 & 1,71 & 3,15 \\
\hline 2 & 0,60 & 1,03 & 1,64 & 1,84 \\
\hline 3 & 0,67 & 1,29 & 2,19 & 1,97 \\
\hline 4 & 0,76 & 1,56 & 2,74 & 2,16 \\
\hline 5 & 0,66 & 1,66 & 3,12 & 1,96 \\
\hline
\end{tabular}




\subsubsection{Função Impulso Resposta}

Figura 2 - Função Impulso Resposta para IDLSP
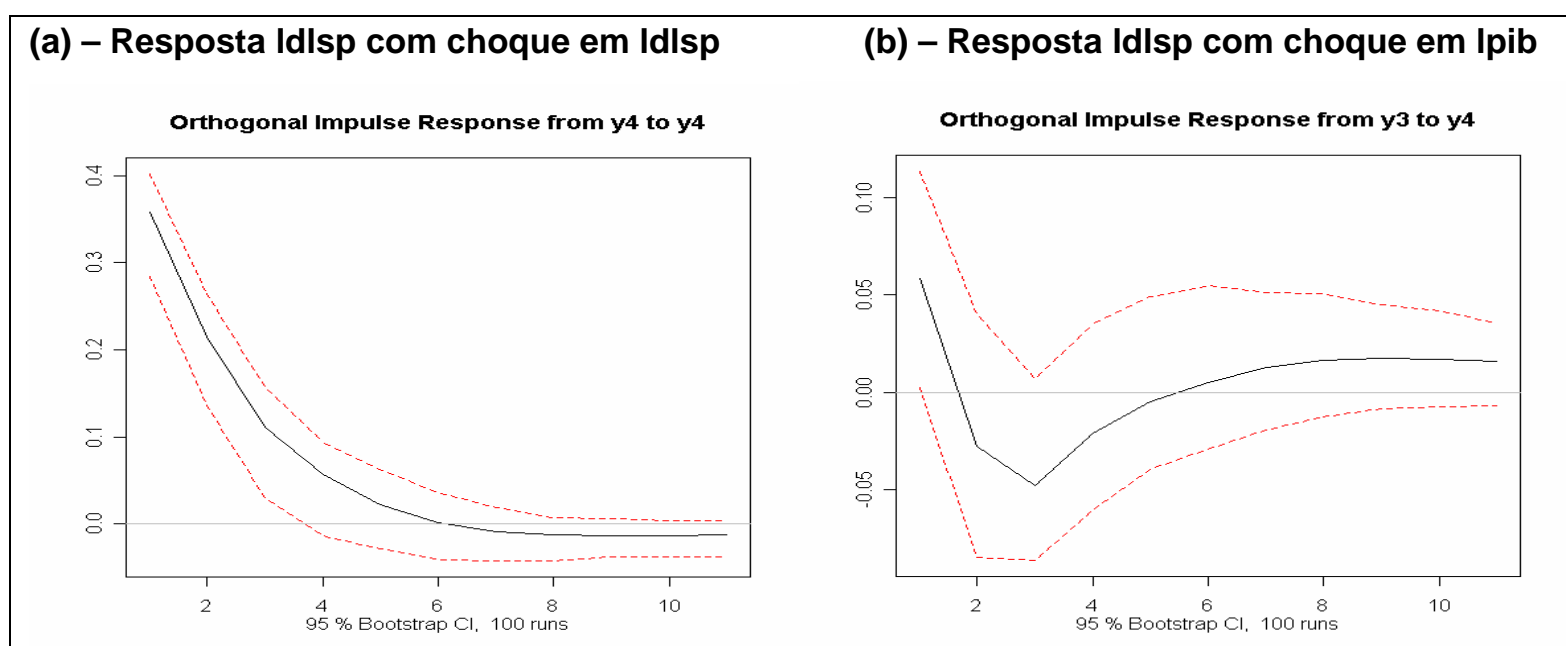

(c) - Resposta do Idlsp com choque jurosreais

(d) - Resposta do Idlsp com choque dlcambio
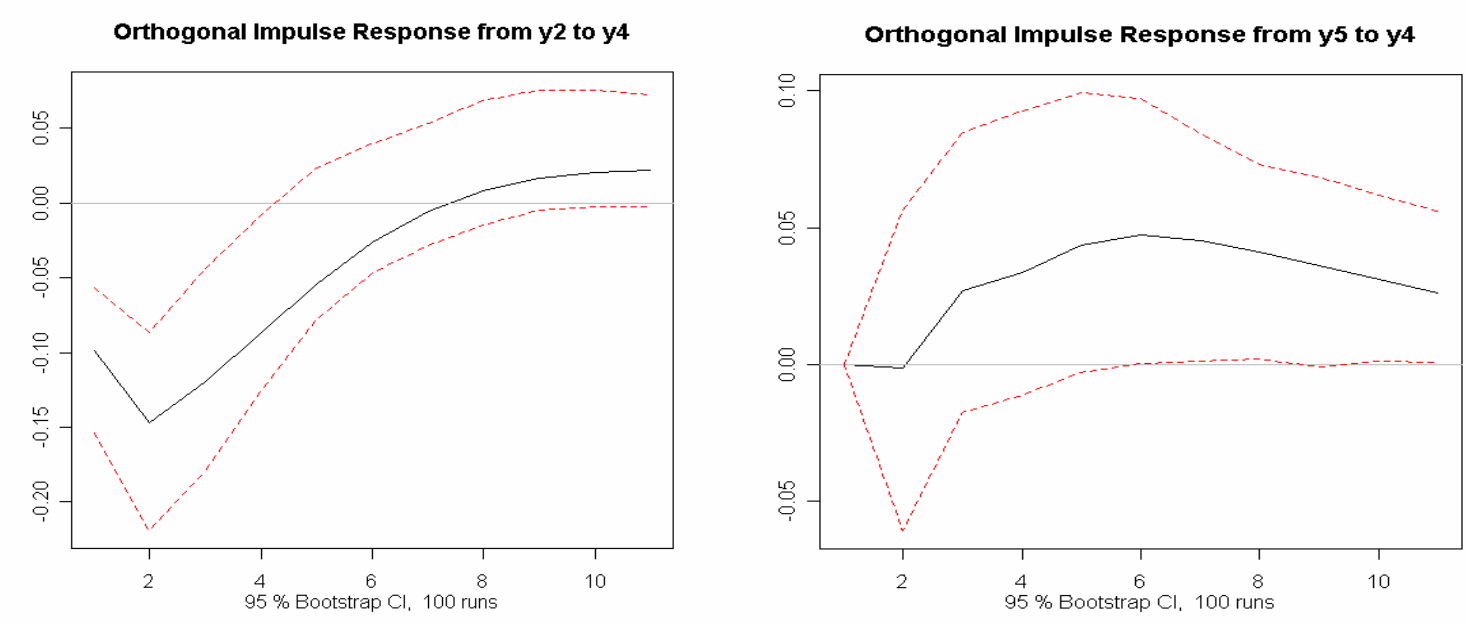

(e) - Resposta do Idlsp com choque em rp

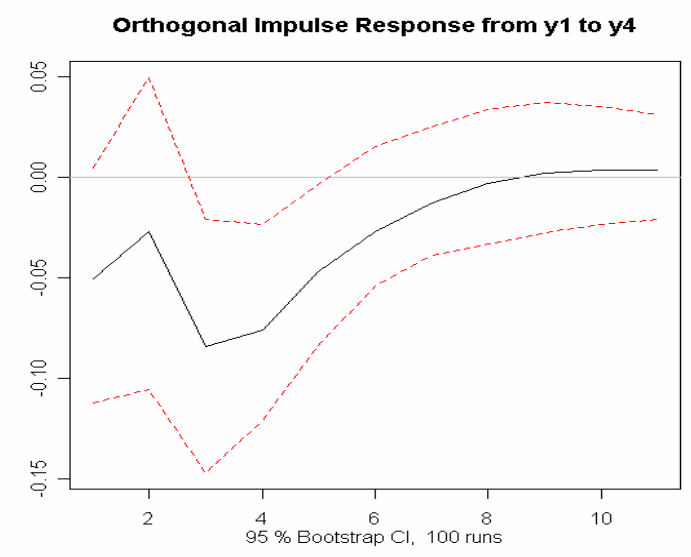


A Figura 2 dos itens a até $e$ apresenta as funções do impulso-resposta da dívida líquida do setor público para choque na própria dívida e nas variáveis condicionantes: o PIB, os Juros Reais, o Câmbio e o Resultado Primário.

Nota-se que a Dívida Líquida do Setor Público - aqui representada por Idsp, apresenta-se sensível a choques em todas as variáveis analisadas. No item a percebe-se que um choque na dívida traz efeitos imediatos sobre ela retomando-se o equilíbrio a partir do sexto período. $O$ item $b$ reflete o efeito que o choque no PIB causa na DLSP. De acordo com esse gráfico, um aumento no PIB traz aumento imediato sobre a dívida, porém a partir do segundo período verifica-se uma queda, normalisando-se a partir do sexto período.

No item $c$, verifica-se que um choque nos juros reais traz efeitos imediatos sobre a dívida, retornando-se ao equilíbrio após o sétimo período. Já um choque no câmbio, de acordo com o item $d$, não causa efeito imediato, mas a partir do segundo período leva a aumentos na dívida, que se prolongam até o oitavo período.

No último item, o item $e$, têm-se os efeitos na dívida com choques no resultado primário. Percebe-se que um aumento no resultado primário traz reduções imediatas na dívida, retornando-se ao equilíbrio após o oitavo período.

\subsubsection{Decomposição da Variância}

Quadro 8 - Resultados para a decomposição da variância (período jan/1995 a dez/2008)

\begin{tabular}{|l|c|l|l|l|r|}
\hline & rp & jurosreais & Ipib & Idlsp & \multicolumn{1}{c|}{ dcambio } \\
\hline$[1]$, & 0.01772523 & 0.0679346 & 0.02367050 & 0.8906697 & $0.000 \mathrm{e}+00$ \\
\hline$[2]$, & 0.01534324 & 0.1469932 & 0.01960678 & 0.8180507 & $6,09 \mathrm{E}-06$ \\
\hline$[3]$, & 0.04153120 & 0.1825950 & 0.02594340 & 0.7470535 & $2,09 \mathrm{E}-03$ \\
\hline$[4]$, & 0.06040934 & 0.1982159 & 0.02578884 & 0.7086789 & $6,91 \mathrm{E}-03$ \\
\hline$[5]$, & 0.06672136 & 0.2035925 & 0.02516788 & 0.6908788 & $2,15 \mathrm{E}-02$ \\
\hline$[6]$, & 0.06845697 & 0.2033639 & 0.02492965 & 0.6817793 & $2,86 \mathrm{E}-02$ \\
\hline$[7]$, & 0.06843051 & 0.2016759 & 0.02527138 & 0.6760522 & $3,43 \mathrm{E}-02$ \\
\hline$[8]$, & 0.06793014 & 0.2003526 & 0.02602313 & 0.6713635 & $3,87 \mathrm{E}-02$ \\
\hline$[9]$, & 0.06744515 & 0.1998395 & 0.02691323 & 0.6671393 & $4,17 \mathrm{E}-02$ \\
\hline$[10]$, & 0.06705408 & 0.2000023 & 0.02775694 & 0.6634294 & $4,39 \mathrm{E}-02$ \\
\hline$[11]$, & 0.06673081 & 0.2005644 & 0.02846244 & 0.6603302 & $4,54 \mathrm{E}-02$ \\
\hline
\end{tabular}




\begin{tabular}{|l|l|l|l|l|r|}
\hline$[12]$, & 0.06645246 & 0.2012967 & 0.02900815 & 0.6578396 & $4,64 \mathrm{E}-02$ \\
\hline$[13]$, & 0.06621705 & 0.2020564 & 0.02941031 & 0.6558730 & $4,70 \mathrm{E}-02$ \\
\hline$[14]$, & 0.06603300 & 0.2027716 & 0.02969807 & 0.6543139 & $4,71 \mathrm{E}-02$ \\
\hline$[15]$, & 0.06590809 & 0.2034157 & 0.02990065 & 0.6530503 & $4,77 \mathrm{E}-02$ \\
\hline$[16]$, & 0.06584441 & 0.2039866 & 0.03004226 & 0.6519913 & $4,81 \mathrm{E}-02$ \\
\hline$[17]$, & 0.06583819 & 0.2044932 & 0.03014111 & 0.6510700 & $4,84 \mathrm{E}-02$ \\
\hline$[18]$, & 0.06588172 & 0.2049481 & 0.03021017 & 0.6502403 & $4,87 \mathrm{E}-02$ \\
\hline$[19]$, & 0.06596561 & 0.2053638 & 0.03025839 & 0.6494714 & $4,89 \mathrm{E}-02$ \\
\hline$[20]$, & 0.06608051 & 0.2057512 & 0.03029187 & 0.6487431 & $4,91 \mathrm{E}-02$ \\
\hline$[21]$, & 0.06621805 & 0.2061192 & 0.03031474 & 0.6480424 & $4,93 \mathrm{E}-02$ \\
\hline$[22]$, & 0.06637130 & 0.2064744 & 0.03032978 & 0.6473607 & $4,94 \mathrm{E}-02$ \\
\hline$[23]$, & 0.06653481 & 0.2068221 & 0.03033888 & 0.6466925 & $4,96 \mathrm{E}-02$ \\
\hline$[24]$, & 0.06670443 & 0.2071659 & 0.03034336 & 0.6460339 & $4,97 \mathrm{E}-02$ \\
\hline
\end{tabular}

Pela decomposição da variância, Quadro 8, confirma-se a análise preliminar realizada a partir da função impulso resposta. Percebe-se que a variação da dívida deve-se em grande parte pela sua própria variação. De acordo com o Quatro 8, no primeiro período, 89\% da variação da dívida explica-se por choques próprios. Esse percentual vai diminuindo gradativamente, chegando a $64 \%$ no vigésimo quarto período.

A variação dos juros reais no primeiro momento é superficial, mas a partir do segundo período o seu percentual vai aumentando, chegando a $20 \%$ a partir do quinto período.

A variação do resultado primário, do PIB e do câmbio inicialmente têm pouca representatividade sobre a variação da dívida, mas têm os percentuais aumentados gradativamente.

Observa-se então que para o período analisado, de janeiro de 1995 a dezembro de 2008, a variação da dívida deve-se primeiramente à sua própria variação, em segundo pela variação dos juros reais. O resultado primário, o câmbio e o PIB respondem juntos por cerca de $15 \%$ da variação da dívida. 


\subsubsection{Modelo VAR para Dívida Líquida do Setor Público - 1999 à 2008}

No item anterior, avaliou-se o período mais amplo, de janeiro de 1995 a dezembro de 2008. Neste item, será repetida a análise apenas para o período de janeiro de 1999 a dezembro de 2008. Essa nova análise possibilitará avaliar os resultados alcançados com a adoção, a partir de 1999, de uma política fiscal severa de obtenção de superávits primários.

Para esse novo período foram realizados os mesmos procedimentos empregados no item anterior. Contudo, a decomposição da variância permitiu uma análise comparativa em relação ao modelo anterior.

Quadro 9 - Resultados para a decomposição da variância (período jan/1999 a dez/2008)

\begin{tabular}{|l|l|l|l|l|l|}
\hline & \multicolumn{1}{|c|}{ dcambio2 } & \multicolumn{1}{|c|}{ Ipib2 } & Idlsp2 & jurosreais2 & \multicolumn{1}{|c|}{ rp2 } \\
\hline$[1]$, & 0.16951700 & 0.005005521 & 0.8254775 & 0.000000000 & 0.00000000 \\
\hline$[2]$, & 0.14062564 & 0.008054629 & 0.8301705 & 0.002359405 & 0.01878988 \\
\hline$[3]$, & 0.10699422 & 0.009816239 & 0.8328399 & 0.004163584 & 0.04618602 \\
\hline$[4]$, & 0.09423828 & 0.009560908 & 0.8179282 & 0.005556892 & 0.07271577 \\
\hline$[5]$, & 0.08681381 & 0.012382408 & 0.7974781 & 0.004653164 & 0.09867252 \\
\hline$[6]$, & 0.07770616 & 0.010542771 & 0.7852757 & 0.004174458 & 0.12230094 \\
\hline$[7]$, & 0.06731888 & 0.010083025 & 0.7696870 & 0.003572444 & 0.14933869 \\
\hline$[8]$, & 0.05901243 & 0.011194964 & 0.7565162 & 0.003128894 & 0.17014749 \\
\hline$[9]$, & 0.05383452 & 0.012678590 & 0.7435392 & 0.002779728 & 0.18716800 \\
\hline$[10]$, & 0.05268411 & 0.015128078 & 0.7286970 & 0.002490922 & 0.20099987 \\
\hline$[11]$, & 0.05480214 & 0.018047120 & 0.7146480 & 0.002297112 & 0.21020561 \\
\hline$[12]$, & 0.05827457 & 0.020585128 & 0.7034544 & 0.002209550 & 0.21547636 \\
\hline$[13]$, & 0.06163536 & 0.022755353 & 0.6956969 & 0.002171164 & 0.21774123 \\
\hline$[14]$, & 0.06425324 & 0.024916628 & 0.6907801 & 0.002202684 & 0.21784739 \\
\hline$[15]$, & 0.06564339 & 0.026902925 & 0.6886471 & 0.002315228 & 0.21649137 \\
\hline$[16]$, & 0.06560811 & 0.028446500 & 0.6891711 & 0.002466544 & 0.21430780 \\
\hline$[17]$, & 0.06432297 & 0.029568212 & 0.6917332 & 0.002617224 & 0.21175842 \\
\hline$[18]$, & 0.06216231 & 0.030410810 & 0.6955346 & 0.002770156 & 0.20912212 \\
\hline$[19]$, & 0.05952461 & 0.031025094 & 0.6999610 & 0.002920997 & 0.20656835 \\
\hline
\end{tabular}




\begin{tabular}{|l|l|l|l|l|l|}
\hline$[20]$, & 0.05677276 & 0.031447782 & 0.7045135 & 0.003050386 & 0.20421558 \\
\hline$[21]$, & 0.05417465 & 0.031764020 & 0.7087431 & 0.003150134 & 0.20216812 \\
\hline$[22]$, & 0.05187327 & 0.032055864 & 0.7123327 & 0.003225569 & 0.20051257 \\
\hline$[23]$, & 0.04990671 & 0.032362860 & 0.7151461 & 0.003280414 & 0.19930392 \\
\hline$[24]$, & 0.04824045 & 0.032712687 & 0.7171634 & 0.003315970 & 0.19856751 \\
\hline
\end{tabular}

$\mathrm{Na}$ decomposição da variância realizada para o período de janeiro de 1999 a dezembro de 2008, apresentada no Quadro 9, a variação da dívida deve-se primeiramente à sua própria variação, em segundo pela variação do resultado primário. O câmbio, o PIB e os juros reais respondem juntos por cerca de $10 \%$ da variação da dívida.

Nota-se que a variação da dívida, assim como na análise anterior, devese em grande parte pela sua própria variação, contudo, o percentual da sua variação que se explica por choques próprios passa para $82 \%$. Esse percentual vai diminuindo gradativamente até o décimo sexto período, quando tem um leve aumento e depois se mantém próximo aos $70 \%$.

Os juros reais, que na análise anterior respondiam por cerca de $20 \%$ da variação, no período de 1999 à 2008 diminuíram sua relevância abruptamente. Já o câmbio e o PIB apresentaram relação semelhante à análise anterior.

O Resultado Primário, que na análise anterior respondia por cerca de 5\% da variação da dívida, no período de 1999 a 2008 passa a ser o segundo fator de maior representatividade da variação da dívida, chegando a $21,5 \%$ no décimo segundo período.

Têm-se então três diferenças básicas entre as duas análises. A primeira refere-se à redução do percentual da dívida explicada por choques próprios, a segunda à redução do percentual explicado pelos juros reais e a terceira ao aumento do percentual explicado pela evolução do superávit primário. 


\section{DISCUSSÃO DOS RESULTADOS E CONCLUSÕES}

Os resultados empíricos apontaram que a Dívida Líquida do Setor Público possui relação de longo prazo com as demais variáveis estudadas. Também se evidenciou a co-integração entre as séries, o que sugeriu a utilização de modelos mais sofisticados para o diagnóstico.

A partir do modelo de vetores auto-regressivo (VAR), examinou-se as relações lineares entre cada variável e os valores defasados dela própria e de todas as demais variáveis. O teste Qui-Quadrado apontou o ordenamento das variáveis estudadas de acordo com o grau de endogeneidade. A classificação das mais endógenas para menos endógena foi: DLSP, PIB, Câmbio, Juros Reais e Resultado Primário. O resultado desse teste indicou que a DLSP é a variável mais endógena, o que significa que choques ou inovações em qualquer outra variável afetam a dívida. O Resultado Primário, por ser a variável com menor grau de endogeneidade, não responde contemporaneamente às inovações das demais variáveis, mas causa impacto em todas elas. Com a utilização da decomposição da variância, percebeuse que cerca de $68 \%$ da variação da dívida decorre da sua própria variação e $18 \%$ decorre da variação dos juros reais. O Resultado Primário, Câmbio e PIB respondem juntos por cerca de $14 \%$ da variação da dívida.

Com o objetivo de avaliar o resultado decorrente da adoção da política fiscal mais severa, a partir de 1999, de obtenção de superávits primários como forma de estabilização da DLSP/PIB, realizou-se a análise para o período de janeiro de 1999 a dezembro de 2008. O resultado da decomposição da variância para esse período divergiu-se em relação à análise anterior no que se refere à participação das variáveis na evolução da dívida. O Resultado primário, que anteriormente respondia por cerca de $5 \%$ da variação da dívida, passa a responder em média por $16 \%$. Houve também aumento na participação do Câmbio e do PIB. Em contrapartida, a participação dos juros reais reduziu-se substancialmente.

Essa evolução se explica pelos resultados obtidos com a adoção de novas estratégias por parte do governo. A partir de 1999 o país passou a obter superávits primários que levaram à redução da necessidade de financiamento. $O$ país obteve também um crescimento médio do PIB para o período 2004 -2008 
superior a 4,5\%. Aliada a essa evolução, houve uma melhora significativa na composição da dívida pública, priorizando a emissão de títulos indexados a índices de preços e a taxas pré-fixadas.

A redução do percentual de participação da dívida decorrente de choques próprios explica-se pela trajetória de queda verificada a partir de 2003. Essa trajetória passa confiança aos agentes de mercado e com isso reduz-se a exigência por elevadas taxas de juros reais.

Outro fator fundamental na análise da evolução da trajetória da dívida trata-se da evolução em relação ao câmbio. À partir de 1999 o país mudou a sistemática de câmbio fixo adotando o sistema de câmbio flutuante. As oscilações cambiais verificadas logo após a adoção desse novo sistema trouxeram impactos imediatos, elevando a dívida. Contudo, a parcela da dívida vinculada a taxas cambiais reduziu-se significativamente a partir de 2003. Com essa redução e com o aumento das reservas cambiais, o país passou a obter mais ativos atrelados ao câmbio que passivos, criando uma proteção para a DLSP contra riscos de mercado.

Além dessa proteção que foi criada com a estabilização da volatilidade cambial e melhora do perfil da dívida, o país vive uma trajetória de estabilidade inflacionária e taxas de juros menores. A conjugação dos fatores: redução da relação DLSP/PIB, taxas de juros menores, crescimento da economia, geração de superávits primários, traz reflexos positivos para toda a economia. Considerando esse cenário, acredita-se que o país tem a possibilidade de romper o círculo vicioso verificado na década de 1990, em que os agentes de mercados exigiam prêmios de risco altos para compensar a exposição ao risco de default .

Para próximos estudos, sugere-se a incorporação de outras variáveis que possam ter influenciado a evolução da dívida, tais como o reconhecimento de dívidas passadas (esqueletos) e as privatizações. Uma outra linha de pesquisa pode ser realizada considerando a evolução dos gastos do governo e sua contribuição para a evolução do endividamento público. 


\section{REFERÊNCIAS}

ALBUQUERQUE, C. M; MEDEIROS, M. B.; FEIJÓ,P.H. Necessidades de Financiamento do Setor Público. In:_ Gestão de Finanças Públicas, 2.ed. Brasília: Coleção Gestão Pública, 2008. cap. 2.

ANDIMA, Séries Históricas. Dívida Pública. In: Dívida Pública - Um Breve Histórico. p.7-12.

BENECKE, D., Dívida Pública - Um tema sem final? In: Dilemas da Dívida. Adenauer Cadernos, Ano III. no. 4. Rio de Janeiro: Fundação Konrad, 2002. p. 199207.

BRESSER-PEREIRA, L.C. Um projeto Nacional de Crescimento com Equidade Social. In: SICSÚ, J.; PAULA, L.F,; MICHEL,R. (orgs). Novo Desenvolvimentismo. Rio de Janeiro: Fundação Konkrad Adenauer,2004. p. 3-47.

BRESSER-PEREIRA, L.C. RIBEIRO, T. Os Efeitos da Poupança Pública Sobre o Crescimento Econômico: Análise para Um Painel de Países In: .Textos para Discussão: Escola de Economia de São Paulo da Fundação Getúlio Vargas. 171, de dezembro de 2008.

BUENO, R. D. L. D.S., Testes da Raiz Unitária. Vetor Auto Regressivo - VAR. In cap.4 Econometria de Séries Temporais.São Paulo: Cengage Learning, 2008. .cap.6.

CAMURI, P. A. Dívida Pública, Política Fiscal e Restrição Externa no Brasil: 19942004. In: Finanças Públicas: X Prêmio Tesouro Nacional, 2005. Coletânea de monografias. Secretaria do Tesouro Nacional. São Paulo: Ágape, 2006. pág. 19-76.

CORREIA, F. M.; MEURES, R. Política Fiscal, Sustentabilidade da Dívida Pública e Liquidez dos Títulos: uma análise para o Brasil. Estudos Econômicos. São Paulo, v.38, n.3, jul./set.2008.

GIAMBIAGI, F.; ALÉM, A.C. A Dinâmica da Dívida Pública e o Caso Brasileiro. In:_. Finanças Públicas: Teoria e Prática no Brasil. 2.ed. Rio de Janeiro: Elsevier, 2001. 
GOLDFAJN, I. Há razões para duvidar que a Dívida Pública no Brasil é Sustentável? In: . Notas Técnicas do Banco Central do Brasil. N. 25, de Julho de 2002.

HERMANN, J. Macroeconomia da dívida pública. In: Dilemas da Dívida Pública. Cadernos Adenauer. Ano III, no. 4, 2002. Rio de Janeiro. Fundação Konrad, 2002. p. 41-70.

HERRERA, S. A dívida Pública Brasileira: Uma perspectiva Internacional.In: Dilemas da Dívida Pública. Cadernos Adenauer. Ano III, 2002, № 4. Rio de Janeiro. Fundação Konrad, 2002. pág.11-39.

LIUSSÁ, F. A. J. Credibilidade e Administração da Dívida Pública: Um Estudo para o Brasil. Dissertação (Mestrado Economia de Empresas) - BNDES. Rio de Janeiro, 1998.

MENDONÇA, F. Evolução recente da Dívida Pública Brasileira.In A Dívida Pública Brasileira. Série cadernos de altos estudos n.ำ 2. Brasília: Câmara dos Deputados, Coordenação de Publicações, 2005.

MUNTADA, R. A trajetória da dívida pública no Brasil após o Plano Real. Aspectos teóricos e avaliação dos instrumentos utilizados na gestão. Dissertação (Mestrado em Economia Empresarial) - Universidade Candido Mendes, Rio de Janeiro, 2006.

RABELO, T.C.S. Crescimento, Endividamento e Política Fiscal: Análise Teórica e uma Aplicação para a Economia Brasileira no Período de 1985-2005. In: XIII Prêmio Tesouro Nacional 2008: Política Fiscal e Dívida Pública. Coletânea de monografias. Secretaria do Tesouro Nacional.

REZENDE, F. Necessidade de Financiamento do Setor Público, Déficits e Dívida Pública. In: Finanças Públicas, 2.ed. São Paulo: Atlas, 2001. cap.15.

SILVA, D. P. D. A Solvência Intertemporal da dívida Interna Brasileira: 19952005. Dissertação (Mestrado em Economia) - Universidade Católica de Brasília, Brasília, 2006.

VERGARA, S.C. Começando a definir a metodologia. In: Projetos e Relatórios de Pesquisa em Administração. 3.ed. São Paulo: Atlas, 2000. cap.4, p.46-53. 